\title{
Global chronostratigraphic correlation of the Llandovery Series (Silurian System) in Iowa, USA, using high-resolution carbon isotope $\left(\delta^{13} \mathrm{C}_{\text {carb }}\right)$ chemostratigraphy and brachiopod and conodont biostratigraphy
}

\author{
CHRISTOPHER B.T. WAID \& BRADLEY D. CRAMER
}

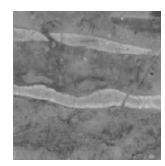

\begin{abstract}
Chronostratigraphic correlation of Silurian units in Iowa is complicated by complex carbonate depositional environments and poor biostratigraphic control. Carbon isotope $\left(\delta^{13} \mathrm{C}_{\text {carb }}\right)$ chemostratigraphy, when integrated with the relatively sparse conodont data, provides an extremely useful chronostratigraphic tool. Here, we integrate conodont biostratigraphic data with carbon isotope chemostratigraphic data $\left(\delta^{13} \mathrm{C}_{\text {carb }}\right)$ for the Llandovery of Iowa. Three carbon isotope excursions were recognized within the Hopkinton and Scotch Grove formations. The late Aeronian (sedgwickii graptolite zone) and likely a heretofore unrecorded Aeronian carbon isotope excursion were recorded from the Hopkinton Formation in the SS-10 Core (Jones County). The Valgu Excursion was recorded from the uppermost Hopkinton Formation through the overlying Buck Creek Quarry Member of the Scotch Grove Formation in the Garrison Core (Benton County). The integration of conodont biostratigraphic and carbon isotope chemostratigraphic data from the Silurian of Iowa allows for the first regional chronostratigraphic correlation of these strata at a resolution finer than stage level. The oxygen and carbon isotope values from the Garrison Core and the evidence for post-diagenetic karstification and fluid movement may provide further evidence that the dolomitization process of the LaPorte City Formation was halted by the influx of meteoric phreatic water. - Key words: Silurian, chronostratigraphy, U.S. Midcontinent, chemostratigraphy.
\end{abstract}

WAID, C.B.T. \& CRAMER, B.D. 2017. Global chronostratigraphic correlation of the Llandovery Series (Silurian System) in Iowa, USA, using high-resolution carbon isotope $\left(\delta^{13} \mathrm{C}_{\text {carb }}\right)$ chemostratigraphy and brachiopod and conodont biostratigraphy. Bulletin of Geosciences 92(3), 373-390 (9 figures, 2 tables). Czech Geological Survey, Prague. ISSN 1214-1119. Manuscript received January 1, 2017; accepted in revised form August 8, 2017; published online September 30, 2017; issued September 30, 2017.

Christopher B.T. Waid, Department of Earth and Environmental Sciences, University of Iowa, 115 Trowbridge Hall, Iowa City, Iowa 52242, USA \& Division of Geological Survey, Ohio Department of Natural Resources, 2045 Morse Road, Building C, Columbus, Ohio 43229, USA; christopher.waid@dnr.ohio.gov •Bradley D. Cramer, Department of Earth and Environmental Sciences, University of Iowa, 115 Trowbridge Hall, Iowa City, Iowa 52242, USA; bradley-cramer@uiowa.edu

The Silurian Period was an interval of profound climatic instability, with seven major climate perturbations over approximately 24 million years (Munnecke et al. 2010, Cramer et al. 2011, Melchin et al. 2012). These climate events were associated with marine extinctions, sea-level change, pulses of glaciation, changes in ocean circulation patterns, and fluctuations in the carbon cycle (Munnecke et al. 2010). Large fluctuations in the global carbon cycle were a pronounced feature of Silurian climate change, and gaining a more precise understanding of the interactions of the carbon cycle, global climate, and biosphere during the Si- lurian may offer valuable geologic context for the co-evolution of life, climate, and the ocean/atmosphere system during the early to middle Paleozoic transition.

Precise and accurate chronostratigraphic correlations are essential for paleoclimatic reconstruction. Correlations between basins must be accurate, because paleoclimate data need to be integrated from as many basins and paleoenvironments as possible to distinguish between local and global environmental changes. The precise timing of geological and biological events in the rock record must also be understood. Climate systems consist of numerous 


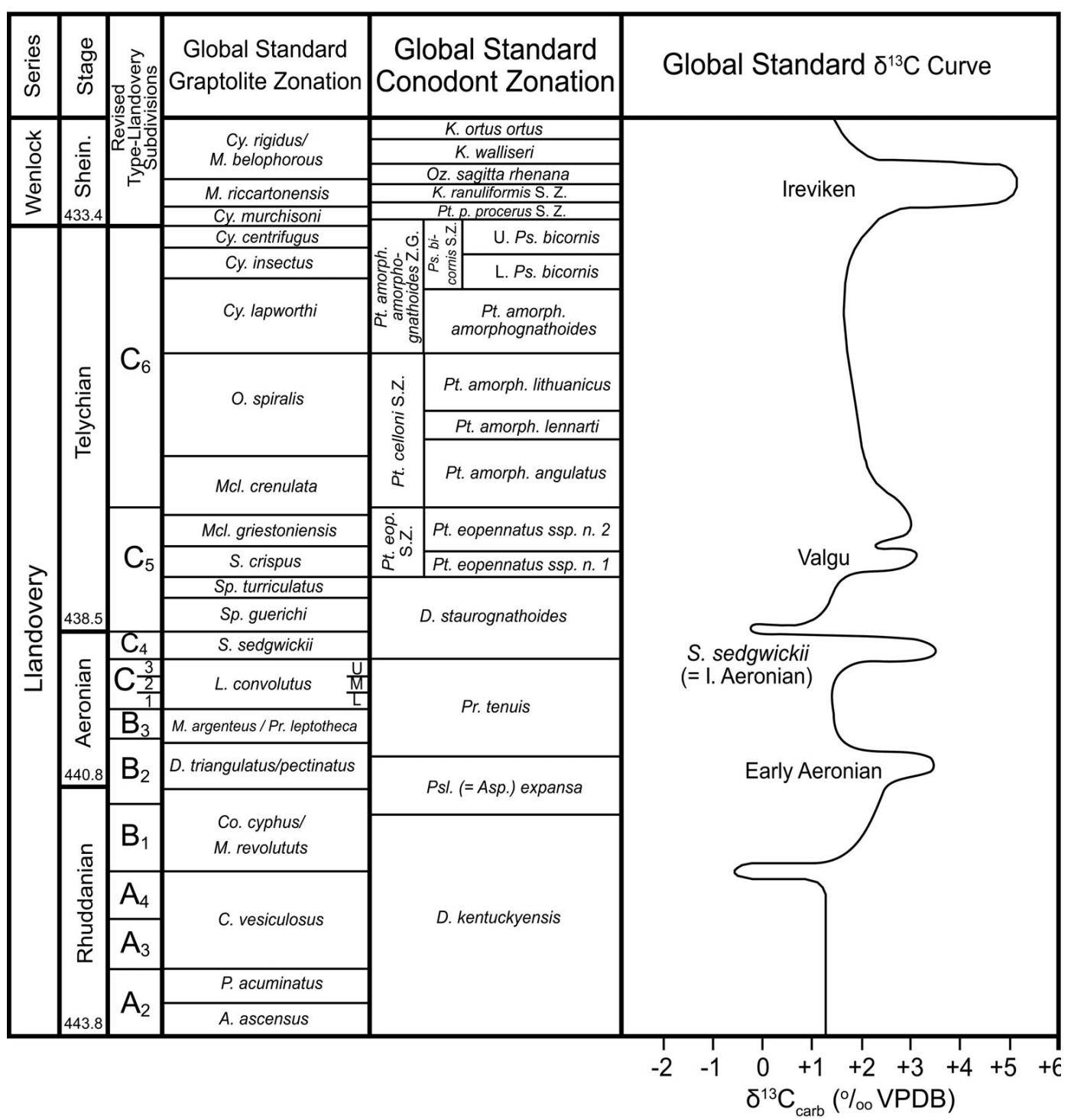

Figure 1. Global standard carbon isotope curve and conodont zonation for the Llandovery and lowermost Wenlock stages (Silurian). Carbon isotope curve from Cramer et al. (2011). Correlation of conodont zonation with chronostratigraphic units and numerical ages of stage boundaries from Melchin $e t$ al. (2012). Position of type Llandovery area subdivisions from Davies et al. (2013, 2016).

chemical and physical cycles that feedback on each other, so it is impossible to determine cause and effect relationships of climate change without high-resolution chronostratigraphic control.

The most precise chronostratigraphic resolution of paleoenvironmental data of the mid-late Llandovery through Ludfordian series is from the Baltic Basin resulting from precise conodont biostratigraphic control and widespread application of carbon isotope chemostratigraphy (e.g., Jeppsson 1997; Kaljo et al. 1997, 1998, 2003, 2012; Männik 1998, 2007a, b; Kaljo \& Martma 2006). The Silurian global standard conodont biozonation and carbon isotope curve for this interval (Fig. 1) are based primarily on data from the Baltic region (Cramer et al. 2011, Melchin et al. 2012). Because the Baltic conodont biozonation was developed relatively recently and high-resolution carbon isotope stratigraphy is a comparatively young technique, there are few similarly resolved comparisons available for paleoenvironmental data from the Baltic with other regions.

\section{The Silurian of lowa}

The East-Central Iowa Basin (Fig. 2) contains carbonate strata spanning much of the Llandovery and Wenlock series that can provide useful paleoenvironmental comparisons with the Baltic, and test the applicability of the Baltic conodont biozonation for global correlation. However, due to the poor biostratigraphic control currently available and 


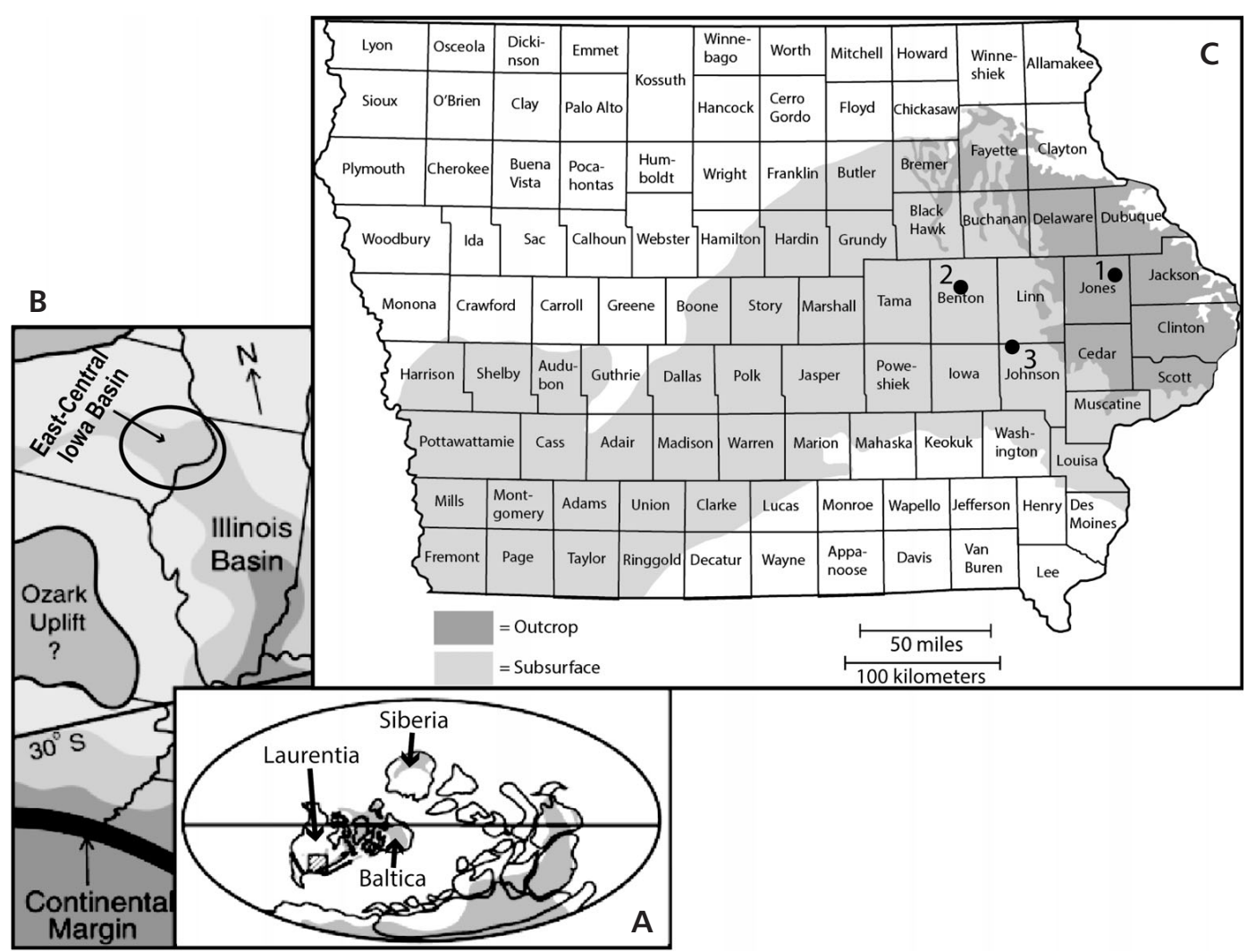

Figure 2. A - paleogeographic map showing the distribution of continents during the middle Silurian. The box on Laurentia represents the approximate location of the Illinois and East-Central Iowa basins. - B - paleogeographic map of the Illinois Basin and surrounding geological features for the early-middle Silurian. Darker shades indicate deeper water. $\bullet$ C county map of Iowa showing the distribution of Silurian strata. Abbreviations: $1-$ location of SS-10 Core; 2 - location of Garrison Core; 3 - location of Knapp Creek Core (McAdams et al. 2017). Distribution of Silurian strata in C from Witzke (1992).

complex carbonate depositional facies variations, the chronostratigraphic correlation of many units from Iowa remains poorly understood. Witzke $(1981,1992)$ thoroughly characterized the facies distribution and lithostratigraphic correlation of the Silurian in Iowa, but could not chronostratigraphically correlate the units with precision finer than stage level. Metzger (2005) provided the first conodont biostratigraphic data from the region that used modern taxonomy and biozonations, but the low conodont yields and the stratigraphically and geographically scattered samples limit its use for detailed chronostratigraphic correlation. Widespread application of integrated high-resolution carbon isotope chemostratigraphy and conodont biostratigraphy is necessary to unravel the complex chronostratigraphic relationships of the Silurian units of Iowa, and is beyond the scope of any one study. This study provides carbon isotope and chronostratigraphic information from two cores that, when combined with new high-resolution conodont biostratigraphic and carbon isotope data from Iowa (McAdams et al. 2017, Waid \& Cramer 2017) provides the first chronostratigraphic framework with a resolution finer than stage level for the Silurian of Iowa.
The Silurian strata of Iowa were deposited in a small structural basin slightly isolated from the Illinois Basin (East-Central Iowa Basin; Fig. 2). The Illinois Basin formed in an extensional system during the formation of the Reelfoot Rift complex during the late Proterozoic (Macke 1995). Thermal subsidence of the thinned crust provided accommodation space for sediments from the latest Proterozoic through to the Carboniferous Period (Macke 1995). During the Silurian, the relatively slow thermal subsidence of the region, combined with its tropical location (Torsvik et al. 1996) and limited clastic input (Johnson 1987) allowed for carbonate-dominated deposition along the basin margins. During the sea-level low of the Early Devonian, much of the Silurian strata were eroded and deposition resumed during the Middle Devonian (Witzke 1992).

The precise chronostratigraphic positions of the Silurian formations of Iowa (Fig. 3) are poorly understood due to the paucity of biostratigraphic information. Most of the units were dolomitized, inhibiting the recovery of well-preserved conodonts useful for biostratigraphy. The Mosalem and Tete des Morts formations were deposited in paleovalleys on the Ordovician Maquoketa Shale. There is 


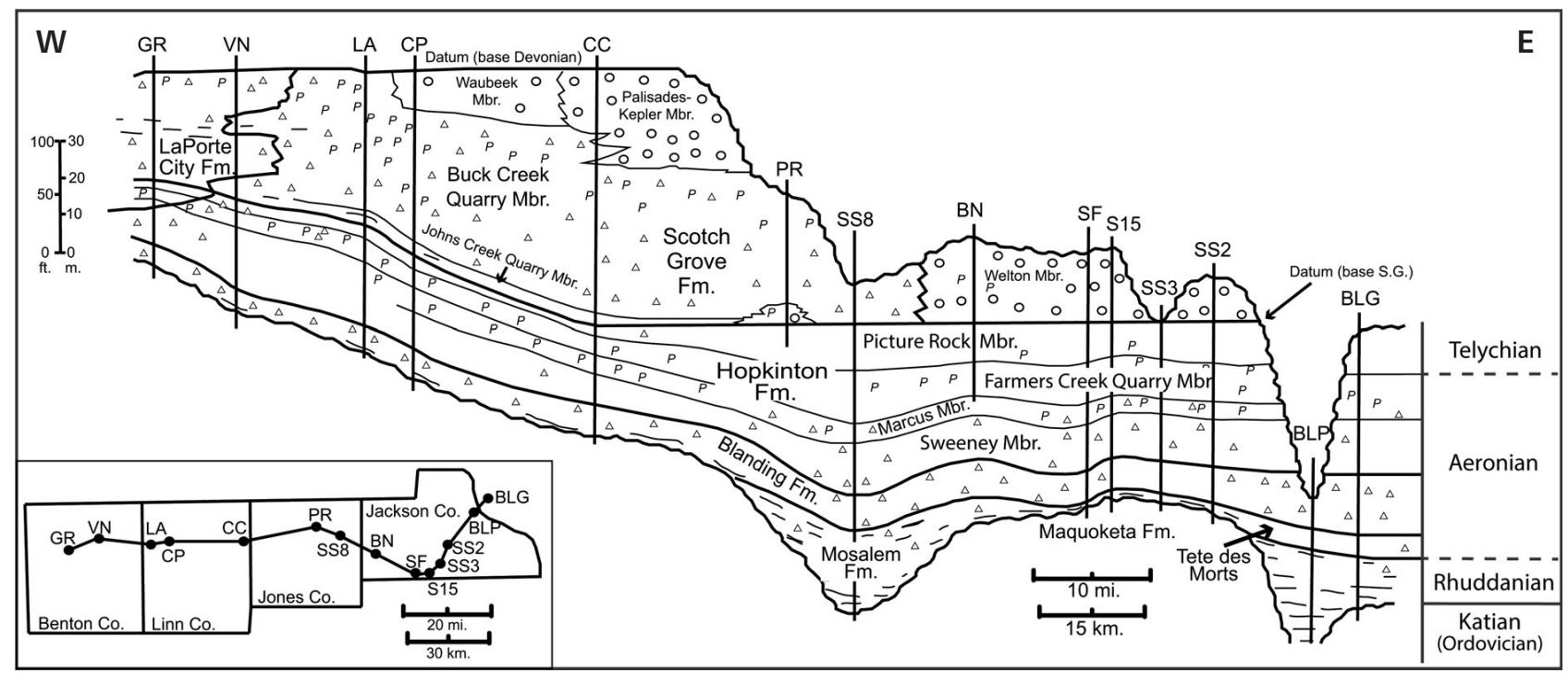

Figure 3. Cross section of Silurian strata in eastern Iowa. The lower two members of the Hopkinton Formation become indistinguishable in the western part of the cross section. The Sweeney and Marcus members are referred to as Lower Hopkinton in this manuscript. Note the change in datum at the CC core in Linn County. All cores and cuttings used in this cross section are stored at the Iowa Geological Survey Core Repository. Abbreviations: GR - Garrison Core, W23440; VN - Vinton City Well \#3 (cuttings), W0025; LA - Lewis Access Core, W23254; CP - Center Point Core, WW23272; CC = Central City (cuttings), W25446; PR = Picture Rock County Park (natural exposure); SS8 - SS-8 Core, W27580; BN - Baldwin North Roadcut and Bluffs (natural exposure); SF - Saunders Core, W27576; SS15 - SS-15 Core, W27587; SS3 - SS-3 Core, W27575; SS-2 - SS-2 Core, W27574; BLP - Bellevue State Park (natural exposure); BLG - Blanding Type Section (natural exposure). Modified from Witzke (1992).

very little biostratigraphic information from the Mosalem Formation, but carbon isotope data indicate that it likely preserves the Ordovician-Silurian boundary (Bergström et al. 2012). Witzke (1981, 1992) assigned the Tete des Morts Formation to the Aeronian Stage based on brachiopod data. The Blanding Formation preserves Aeronian brachiopods (Johnson 1983) and is the lowest formation in Iowa to overlie contiguously the topographic highs of the eroded Maquoketa Shale (Fig. 3).

The Hopkinton Formation overlies the Blanding Formation, and is divided into four formal members (Fig. 3). The informal designation of 'lower Hopkinton member' (= Sweeney and Marcus members) is used in this study, because the Sweeney and Marcus members cannot be differentiated in the study area (see western end of Fig. 3). Whereas virtually no biostratigraphically useful conodonts have been found in the Hopkinton Formation, abundant moldic preservation of brachiopods provides some biostratigraphic constraint. The brachiopod Stricklandia lens progressa was recorded in the lower Hopkinton Formation (Johnson 1977), which correlates to a position in $\mathrm{C}_{3}$ of the Welsh Basin Llandovery (WBL) subdivision of Jones (1925; revised in Davies et al. 2013). Stricklandia laevis occurs in the overlying Farmers Creek Member, which correlates to a $\mathrm{C}_{4}$ position (Boucot \& Ehlers 1963; Johnson 1983; Davies et al. 2013, 2016). The stratigraphic revisions to the type Llandovery area of Davies et al. (2013, 2016) indicate that the GSSP for the Telychian Stage is not at the base of $\mathrm{C}_{4}$ (= base of Wormwood Forma- tion), but is actually in the middle of the formation. Therefore, the first occurrence of S. laevis can no longer be used as a marker for the base of the Telychian. Furthermore, the first occurrence of the graptolite Spirograptus guerichi, the primary fossil used for global correlations to the base of the Telychian Stage, is in the Cerig Formation (WBL $\mathrm{C}_{5}$ ), which overlies the Wormwood Formation (Davies et al. 2013, 2016). Therefore, the Farmers Creek Member is of latest Aeronian age based on brachiopod data. The Picture Rock Member overlies the Farmers Creek Member, and contains the late Aeronian through early Telychian brachiopod Pentamerus oblongus at its base (Johnson 1983), and Telychian (WBL $\mathrm{C}_{5}$ ) Pterospathodus eopennatus Superzone conodonts in the upper part (Witzke 1981). This means that the Aeronian-Telychian boundary in Iowa lies within the Picture Rock Member or between the Farmers Creek and Picture Rock members (McAdams et al. 2017).

The Scotch Grove Formation overlies the Hopkinton, and is separated into five members (Fig. 3). The members represent slightly different carbonate depositional facies, which causes the geographic position and chronostratigraphic correlation of the members to be problematic, and the contacts between the members can be diachronous in different regions. McAdams et al. (2017) recovered conodonts diagnostic of the Pterospathodus eopennatus Superzone in the Johns Creek Quarry (JCQ) Member and recorded the Valgu Excursion, both of which indicate a lower Telychian position. 


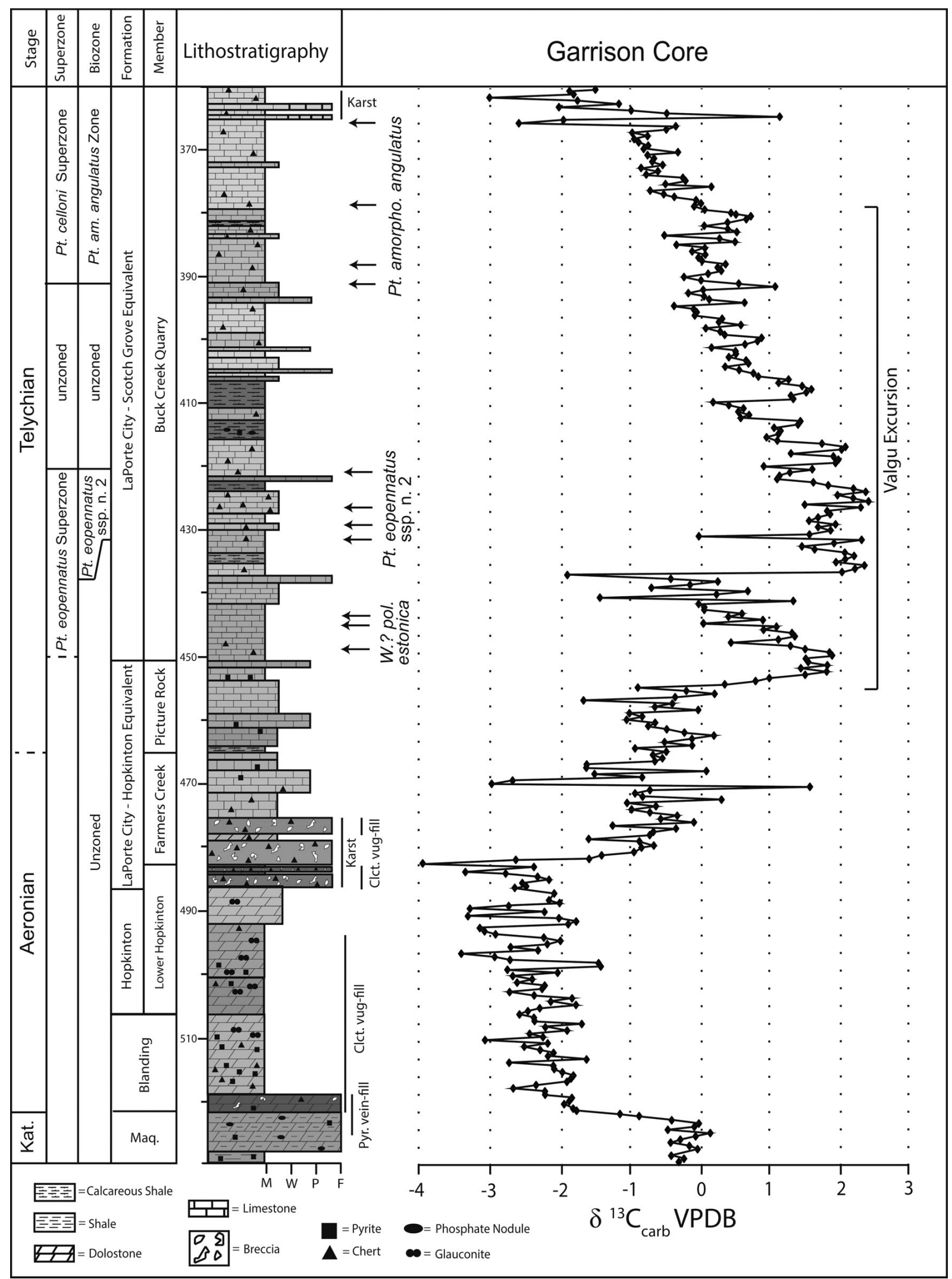

Figure 4. Stratigraphic column and carbon isotope curve from the Garrison Core. Conodont zonation from Waid \& Cramer (2017). Note the scatter of the data, and negative shift in isotope values below karstified beds. Depth scale in feet. Colors represent the dominant color of the rock. 


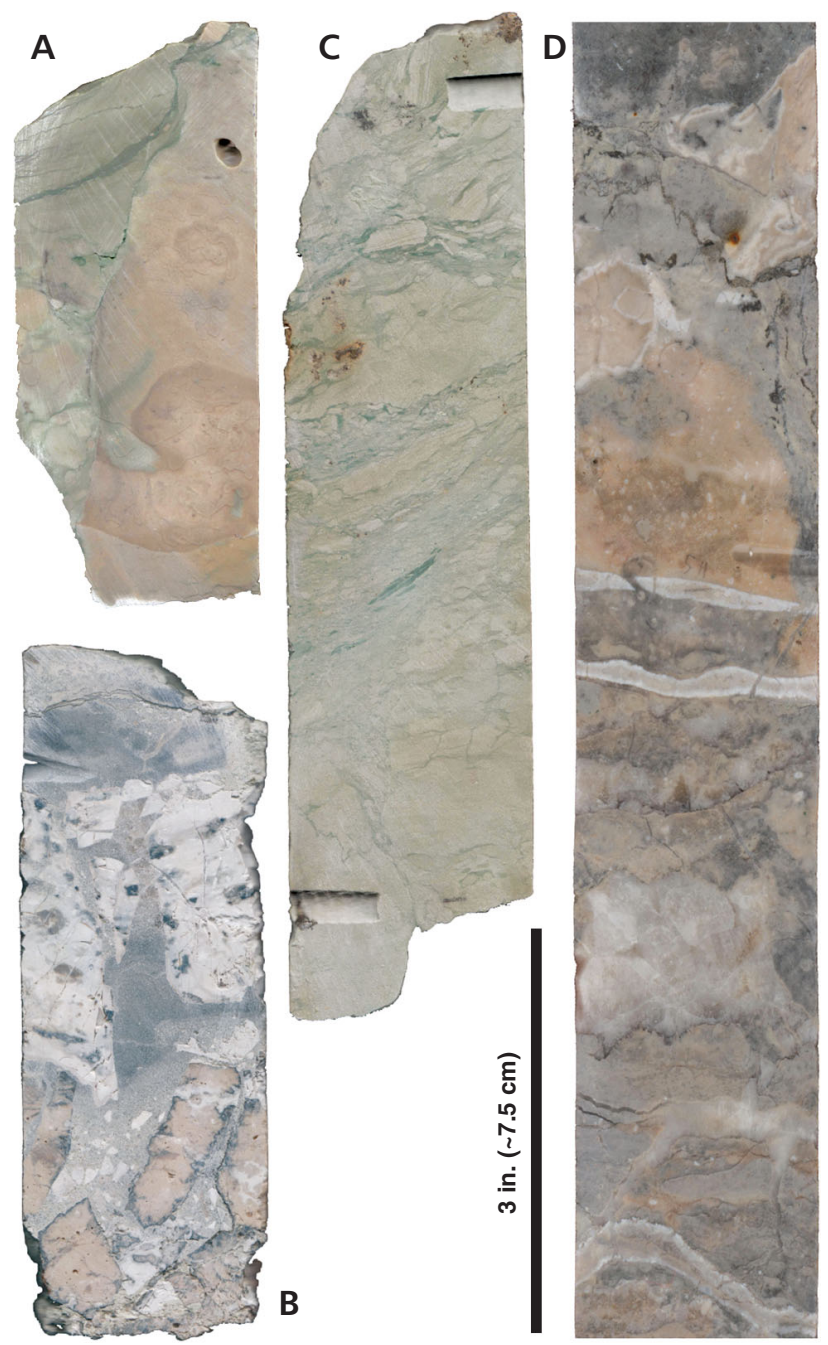

Figure 5. Scanned sections from the Garrison Core. $\bullet A$ - karstic surface from the BCQ Member (363 feet). • B - brecciated chert indicating karstification from the Farmers Creek Member (480 feet). $\bullet \mathrm{C}$ - floatstone from the top of the Maquoketa Formation. Note the angular intraclasts of tan dolomudstone. - D - calcite-vug and fracture-fill from the Lower Hopkinton Formation (511 feet).

The LaPorte City Formation is laterally equivalent to most of the Hopkinton Formation and Buck Creek Quarry (BCQ) Member of the Scotch Grove Formation (Fig. 3). The general lithological characteristics used to distinguish the members of the Hopkinton Formation and BCQ Member are present in the LPC, but it was defined as a separate formation because it was not dolomitized. The dolomitization process of the LPC was apparently halted by the influx of meteoric fresh water during subaerial exposure during the sea-level lowstand at the Silurian-Devonian boundary (Witzke 1981, 1992; Ludvigson et al. 1992).

Conodonts diagnostic of the Pterospathodus eopennatus Superzone through Pterospathodus amorphognathoides angulatus Biozone were recovered from the portion of the LaPorte City (LPC) Formation that is stratigraphically equivalent to the BCQ Member in Benton and Delaware counties, Iowa (Waid \& Cramer 2017; Fig. 9). In Johnson County, McAdams et al. (2017) recovered conodonts diagnostic of the Pt. amorph. angulatus Zone at the base of the BCQ Member in Johnson County, and Pt. amorph. amorphognathoides (Walliser, 1964), the nominal subspecies of the Pt. amorph. amorphognathoides Zonal Group, in the lower half of the BCQ Member. They also identified the early Sheinwoodian Ireviken Excursion in the Welton and Waubeek members, which restricts the Telychian-Sheinwoodian boundary to the Welton Member in Johnson County, Iowa. The data from Waid \& Cramer (2017) and McAdams et al. (2017) indicate that the BCQ Member is diachronous but restricted to the Telychian Stage in Benton and Johnson counties. The lower part of the BCQ appears to be chronostratigraphically equivalent (Pt. eopennatus Superzone) to the JCQ Member in regions where the JCQ Member is absent. The Palisades-Kepler and Waubeek members are an interfingered carbonate mound and mound-flank debris facies that overlies, and is sometimes laterally equivalent to, the upper parts of the Welton and BCQ members (Witzke 1992). The recovery of Ozarkodina sagitta rhenana (Walliser, 1964) from the Waubeek member by Metzger (2005) indicates that the Palisades-Kepler/Waubeek members range no higher than the Sheinwoodian Stage. The uppermost Silurian unit in Iowa is the Gower Formation. It contains a mixture of mound carbonates and laminated mudstones that represent deposition in a restricted marine setting, as well as crinoid-rich limestones indicating an open marine environment (Witzke 1992). The Gower Formation contains brachiopods indicative of the Wenlock Series, but its uppermost extent is not precisely known (Witzke 1992).

The focus of this study is the Blanding, Hopkinton, and LPC formations, and the BCQ Member of the Scotch Grove Formation. The Maquoketa, Blanding, Hopkinton, and LaPorte City formations in the Garrison Core, drilled in the central part of Benton County (Fig. 2), were sampled for carbon isotope data, and samples for conodont processing were collected below the interval studied in Waid \& Cramer (2017). The Garrison Core was selected for analysis because it was previously sampled for conodonts (Metzger 2005, Waid \& Cramer 2017) and contains the thickest known section of the LPC, providing a useful reference section for the formation. Isotope samples were collected from the Blanding and Hopkinton formations, and BCQ Member of the Scotch Grove Formation in the SS-10 Core, drilled in the northeast part of Jones County (Fig. 2). The $\mathrm{SS}-10$ core was too small [1 inch $(\sim 2.5 \mathrm{~cm})$ diameter] to process for conodonts, but was chosen for isotope analysis because it contains exceptionally thick Blanding and Hopkinton formations. 


\section{Lithologic Descriptions}

In the Garrison Core (Fig. 4), the Maquoketa Formation consists of soft green shale containing abundant pyrite at the base of the core, overlain by a floatstone bearing greenish-tan dolomitic mudstone intraclasts. The base of the Blanding Formation, as interpreted herein, is a gray, dolomitic brecciated chert bed. The rest of the Blanding Formation is predominantly gray to slightly greenish gray dolo-mudstone with abundant chert nodules throughout, and glauconite pellets at the top. Disseminated and nodular pyrite is relatively abundant throughout the formation. The lower Hopkinton is composed mainly of breccia beds with angular chert clasts surrounded by a gray to tannish gray, slightly sandy mud matrix, and bio-dolo-mud- to wackestones. The part of the LPC Formation equivalent to the Farmers Creek Member consists of brecciated chert beds as well as bio-mud- to packstones containing disarticulated crinoid debris. The part of the LPC Formation equivalent to the Picture Rock Member is a green calcareous shale to mudstone at its base, and the rest of the unit consists of bio-wacke- to bio-packstones. There is occasional disseminated pyrite throughout all three members of the Hopkinton, and chert nodules are abundant in the Farmers Creek Member and occur occasionally in the Picture Rock Member. The part of the LPC Formation that is equivalent to the BCQ Member consists of tan to greenish gray biomudstones to wackestones bearing disarticulated crinoid debris. Green mud stringers are common throughout the interval, and the middle of the BCQ Member contains very argillaceous biomudstones and calcareous green shales. Chert nodules are scattered throughout the unit, and occasional phosphate nodules and pyrite are present throughout the more argillaceous middle section. Several karst surfaces are present at the top of the BCQ Member, and the breccia beds of the Hopkinton Formation are interpreted to represent heavily karstified areas (Fig. 5A, C). Large, calcite-filled vugs and veins are present throughout the Blanding Formation (Fig. 5D). The floatstone below the breccia layer in the Blanding Formation (Fig. 5B) was previously assigned to this formation (e.g., Witzke 1981), but based on conodont data, is likely a part of the Maquoketa Formation (see Discussion).

Much of the Farmers Creek and Picture Rock members of the Hopkinton Formation broke apart and was ground down during the coring process of the SS-10 core (Fig. 6) due to the highly porous nature of the rock and the small diameter of the core. Frequent depth markers throughout the core allowed for reasonably accurate (within 2 to 3 feet) estimations of the missing footage. The Blanding Formation consists of gray, slightly argillaceous and cherty dolomudstones and wackestones in the lower half, and lighter gray to greenish gray cherty bio-dolowackestones at the top. The lower Hopkinton Formation consists of green- ish tan to greenish gray bio-dolo-mud- and wackestones. Chert nodules are present at the top and near the bottom of the member. The Farmers Creek Member consists of gray bio-dolo-wacke- to packstones, and has abundant moldic porosity. The Picture Rock Member is predominantly more tan in color than the Farmers Creek Member and has abundant moldic porosity. Chert is absent in both the Farmers Creek and Picture Rock members. The BCQ Member of the Scotch Grove Formation consists of gray, cherty, bio-dolo-wacke- to packstones with abundant disarticulated crinoid debris.

\section{Methods}

Fine-grained carbonate material was sampled for isotope analysis from the Garrison and SS-10 cores using a power drill. Micritic and fine-grained material preserves oceanic carbon isotope values with enough accuracy and precision for chemostratigraphic purposes (Saltzman 2002, Saltzman \& Thomas 2012). Even where skeletal fragments were unavoidable in crinoidal packstone layers, micritic material remained the majority of sampled lithology. Samples were collected at approximately 6 inch $(15 \mathrm{~cm})$ spacing for both cores; 339 samples were taken from the Garrison Core, and 347 from the SS-10 core. Isotope analyses for the samples from the Garrison Core were performed at the W.M. Keck Paleoenvironmental and Environmental Stable Isotope Laboratory at the University of Kansas. The powdered carbonate material was reacted with phosphoric acid, and the carbon and oxygen isotopic ratios of the degassed $\mathrm{CO}_{2}$ measured using a ThermoFinnigan MAT 253 mass spectrometer. NBS-18, TSF-1, Sigma Calcite, and CALX standards were used for carbon and oxygen isotope value calibrations. Two standards were analyzed after every 14 to 16 sample analyses to correct for instrument drift. Isotope analysis of the samples from the SS-10 Core was performed at the Stable Isotope Lab at Iowa State University. The powdered carbonate material was reacted with $75^{\circ}$ phosphoric acid, and the isotopic ratios of carbon and oxygen of the degassed $\mathrm{CO}_{2}$ measured using a ThermoFinnigan MAT Delta Plus XL mass spectrometer in continuous flow mode. Gas samples were collected using a CombiPAL autosampler. NBS-18, NBS-19, and NIST LSVEC standards were used for carbon isotope corrections. NBS-18 and NBS-19 were used for oxygen isotope corrections. All data are reported as deviations in parts per mille (\%o) from the Vienna Peedee Belemnite standard (VPDB).

Samples for conodont processing were collected at approximately 4 foot $(1.2 \mathrm{~m})$ intervals. Each sample weighed approximately $0.5 \mathrm{~kg}$, and was roughly 10 inches $(25 \mathrm{~cm})$ long. Samples were dissolved in a $10 \%$ formic acid solution double-buffered with calcium carbonate and calcium phosphate powder (Jeppsson \& Anehus 1995). The insol- 
uble residue was washed through 1.0 and $0.063 \mathrm{~mm}$ sieves. Density separation was performed on the material collected from the $0.063 \mathrm{~mm}$ sieve using lithium metatungstate at a density of $2.84 \mathrm{~g} / \mathrm{ml}$. Specimens were picked from the heavy fraction, and photographs of representative specimens were taken using a Canon digital camera and processed with Zerene image stacking software. Figured conodont specimens are stored in the Paleontology Repository in the Department of Earth and Environmental Sciences at the University of Iowa.

\section{Results}

The $\delta^{13} \mathrm{C}$ values from the SS-10 core range from -1.25 to $+4.92 \%$ (Fig. 6; Table 1). Values show more variation in the top part of the core (BCQ Member) than lower in the core (Blanding through Hopkinton formations). Missing intervals higher in the core make baseline values difficult to distinguish, but the lowest values are scattered around $+1 \%$ o. There are two distinct and relatively continuous variations from baseline. The lowest occurs in the lower Hopkinton Formation, where values decrease from a baseline value of +1 to near $0 \%$, rise to a maximum of $+1.87 \%$, and then return to near $0 \%$. The second variation from baseline values occurs in the Farmers Creek Member. Isotope values rise from a baseline of around $+1 \%$ o to a maximum of $+4.9 \%$. Elevated $\delta^{13} \mathrm{C}$ values occur throughout the entire Farmers Creek Member, and decrease rapidly across the contact between the Farmers Creek and Picture Rock members.

The $\delta^{13} \mathrm{C}$ values from the Garrison Core range from -4.20 to $+2.15 \%$ o (Fig. 4 ; Table 2). Isotope values are somewhat noisy throughout the entire core, and all values are isotopically light compared with the isotope data from McAdams et al. (2017) for the same interval. In the lower part of the core, values decrease from approximately $-0.5 \%$ in the Maquoketa Formation to baseline values that scatter from -2 to $-3 \%$ in the Blanding and lower Hopkinton formations. Values abruptly shift to a baseline of about $-1 \%$ in the Farmers Creek Member. There is a pronounced increase in $\delta^{13} \mathrm{C}$ values to a maximum of $+1.64 \%$ in the upper Picture Rock Member. Values steadily decrease upwards in the lowermost part of the BCQ Member, and rapidly increase again at approximately 438 feet in the core, to a maximum value of $2.15 \%$. The $\delta^{13} \mathrm{C}$ values steadily decrease for the rest of the BCQ Member, with the exception of very scattered values in the uppermost 6 feet of the core. The $\delta^{13} \mathrm{C}$ and $\delta^{18} \mathrm{O}$ (VPDB) values from the Garrison Core were plotted against each other to test for the influence of diagenetic alteration of the isotope values (Fig. 7; see Discussion).

Conodont yields for the Hopkinton and Blanding formations were exceptionally poor, with only one to three simple-cone elements recovered from each sample. The specimens were too poorly preserved to identify to the species level, but they are likely species of Panderodus Ethington, 1959. Numerous very poorly to fairly well preserved fragments of complex conodonts were recovered from the lowest two samples (Fig. 8). Many of the specimens can be confidently assigned to Amorphognathus Branson \& Mehl, 1933, but are too fragmented for specific identification (Fig. 8F-H). A few well-preserved specimens (Fig. 8A-E) can be assigned to Plectodina furcata inclinata (Glennister, 1957).

\section{Discussion}

The SS-10 core definitively records two positive $\delta^{13} \mathrm{C}$ excursions; a small one in the middle of the lower Hopkinton Formation, and a large one in the Farmers Creek Member (Fig. 6). Although peak values of the lowest excursion are only about $+1 \%$ o higher than baseline, the consistent increase in isotope values below the peak and the consistent decrease in values above the peak create an isolated deviation from baseline. Much of the Farmers Creek Member was missing due to core loss while drilling, but every isotope sample except for one outlier is +2.5 to $+4 \%$ o higher than baseline values. McAdams et al. (2017) recorded a large excursion in the Farmers Creek Member in Johnson County, Iowa, which almost certainly correlates with the large excursion in the Farmers Creek Member of the SS-10 core from Jones County presented here. As discussed above, and in McAdams et al. (2017), the Farmers Creek Member contains brachiopods diagnostic of Llandovery $\mathrm{C}_{4}$, and therefore this excursion is considered equivalent to the $\delta^{13} \mathrm{C}_{\text {org }}$ excursion recorded in the Stimulograptus sedgwickii Biozone (e.g., Melchin \& Holmden 2006, Štorch \& Frýda 2012, Melchin et al. 2015). The sharp decrease in isotopic values across the base of the Picture Rock Member may represent a stratigraphic break, or possibly the onset of the negative carbon isotope excursion that occurs at the Aeronian-Telychian boundary (see Cramer et al. 2011; Fig. 1).

The small excursion in the lower Hopkinton of the SS-10 Core is likely a heretofore unrecorded isotope excursion in the Aeronian Stage. It cannot be the "lower Aeronian" excursion of Cramer et al. (2011; Fig. 1) because the lower Hopkinton contains brachiopods correlating to $\mathrm{WBL} \mathrm{C}_{3}$ (Johnson 1983). WBL $\mathrm{C}_{3}$ spans the upper Lituigraptus convolutus Biozone to just above the base of the Stimulograptus sedgwickii Biozone, whereas the lower Aeronian excursion is restricted to the Demirastrites triangulatus-Demirastrites pectinatus biozones (Cramer et al. 2011, Davies et al. 2013). It also does not appear to correlate with other isotope excursions that have been recorded from upper Aeronian strata. Štorch \& Frýda (2012) 
Christopher B.T. Waid \& Bradley D. Cramer • Chronostratigraphic correlation of the Llandovery Series in lowa

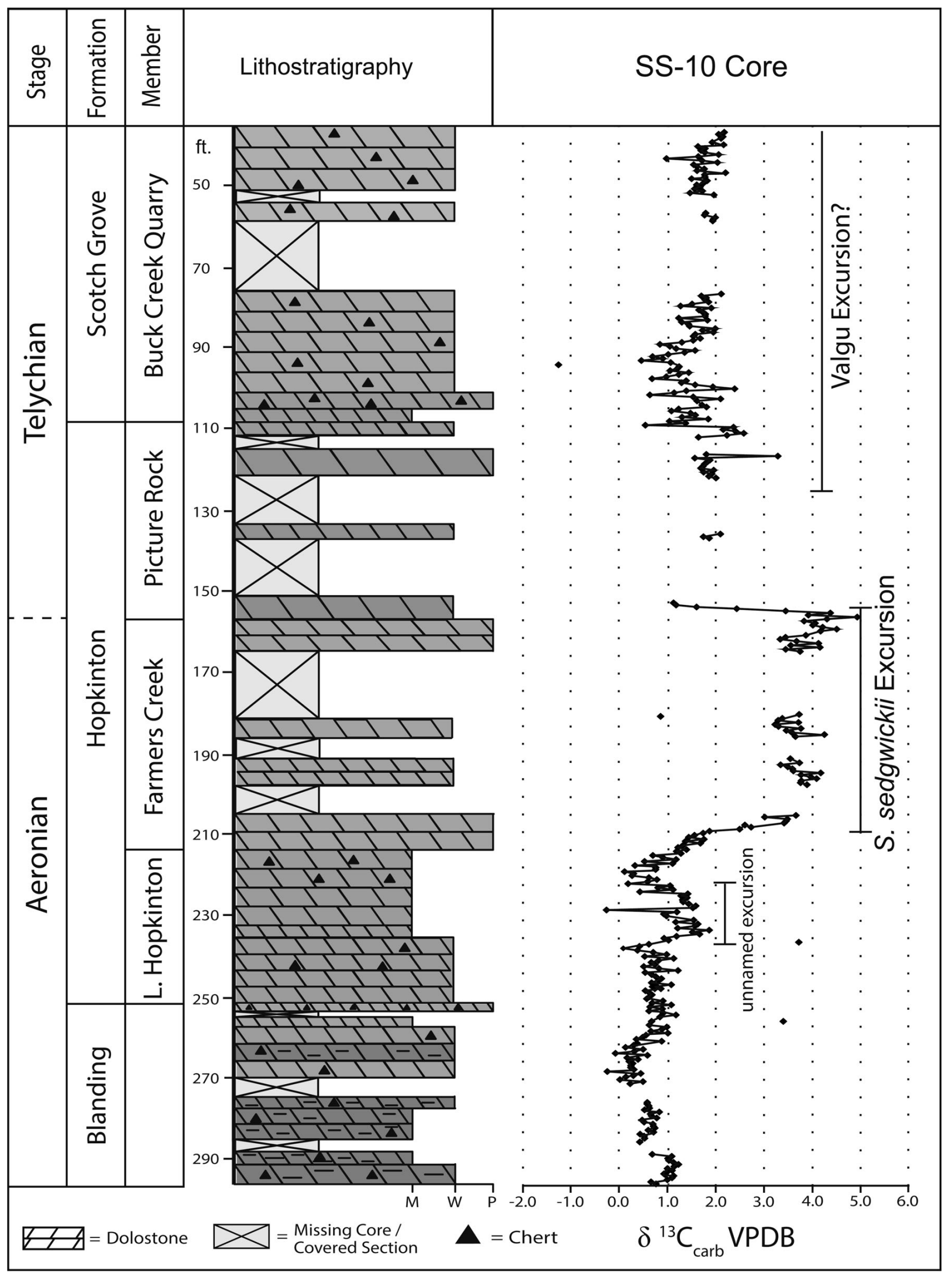

Figure 6. Stratigraphic column and carbon isotope curve for the SS-10 Core. Depth scale in feet. 
Table 1. SS-10 Core Isotope Data.

\begin{tabular}{|c|c|c|c|c|c|c|c|c|c|c|c|}
\hline Sample \# & Depth (ft) & $\delta^{13} \mathrm{C}$ VPDB & Sample \# & Depth (ft) & $\delta^{13} \mathrm{C}$ VPDB & Sample \# & Depth (ft) & $\delta^{13} \mathrm{C}$ VPDB & Sample \# & Depth (ft) & $\delta^{13} \mathrm{C}$ VPDB \\
\hline S-1 & 35 & 2.18 & S-47 & 79.5 & 1.73 & S-93 & 102.5 & 1.72 & S-139 & 158 & 4.50 \\
\hline S-2 & 35.5 & 2.06 & S-48 & 80 & 1.79 & S-94 & 103 & 1.81 & S-140 & 158.5 & 4.17 \\
\hline S-3 & 36.08 & 2.15 & S-49 & 80.5 & 1.78 & S-95 & 103.5 & 1.24 & S-141 & 159 & - \\
\hline S-4 & 36.5 & 2.11 & $\mathrm{~S}-50$ & 81 & 1.24 & S-96 & 104 & 1.09 & S-142 & 159.5 & 3.86 \\
\hline S-5 & 37 & - & S-51 & 81.5 & 1.83 & S-97 & 104.5 & 1.48 & S-143 & 160 & 3.44 \\
\hline S-6 & 37.5 & 1.93 & S-52 & 82 & 1.30 & S-98 & 105 & 1.58 & S-144 & 160.5 & 3.33 \\
\hline S-7 & 38.08 & 2.17 & S-53 & 82.5 & 1.44 & S-99 & 105.5 & 1.31 & S-145 & 161 & 3.67 \\
\hline S-8 & 38.5 & 1.64 & S-54 & 83 & 1.46 & S-100 & 106 & 1.85 & S-146 & 161.5 & 4.13 \\
\hline S-9 & 39 & 1.78 & S-55 & 83.58 & 1.99 & S-101 & 106.5 & 1.05 & S-147 & 162 & 3.55 \\
\hline S-10 & 39.5 & 1.70 & S-56 & 84 & 1.73 & S-102 & 107 & 1.38 & S-148 & 162.5 & 4.15 \\
\hline S-11 & 40 & 1.77 & S-57 & 84.5 & 1.95 & S-103 & 107.5 & 0.55 & S-149 & 163 & 3.45 \\
\hline S-12 & 40.5 & 2.06 & S-58 & 85 & 1.58 & S-104 & 108 & 2.37 & $S-150$ & 163.5 & 3.74 \\
\hline S-13 & 41 & 1.64 & S-59 & 85.5 & 1.54 & S-105 & 108.58 & 2.16 & S-151 & 179.08 & 3.72 \\
\hline S-14 & 41.5 & 0.98 & S-60 & 86 & 1.68 & S-106 & 109 & 2.41 & S-152 & 179.58 & 0.86 \\
\hline S-15 & 42 & 1.72 & S-61 & 86.5 & 1.54 & S-107 & 109.5 & 2.58 & S-153 & 180.08 & 3.38 \\
\hline S-16 & 42.5 & 2.04 & S-62 & 87 & 1.30 & S-108 & 110 & 2.24 & S-154 & 180.58 & 3.29 \\
\hline S-17 & 43 & 1.55 & S-63 & 87.5 & 0.85 & S-109 & 110.5 & 1.65 & S-155 & 181.08 & 3.71 \\
\hline S-18 & 43.5 & 1.62 & S-64 & 88 & 1.05 & S-110 & 115.08 & 1.81 & S-156 & 181.58 & 3.23 \\
\hline S-19 & 44.08 & 1.76 & S-65 & 88.56 & 1.18 & S-111 & 115.5 & 3.29 & S-157 & 182.08 & 3.30 \\
\hline S-20 & 44.5 & 1.61 & S-66 & 89 & 1.58 & S-112 & 116 & 1.57 & S-158 & 182.58 & 3.76 \\
\hline S-21 & 45 & 2.21 & S-67 & 89.5 & 1.36 & S-113 & 116.5 & 1.88 & S-159 & 183.08 & 3.46 \\
\hline S-22 & 45.5 & 1.77 & S-68 & 90 & 1.02 & S-114 & 117 & 1.82 & S-160 & 183.58 & 3.58 \\
\hline S-23 & 46.08 & 1.78 & S-69 & 90.5 & 0.70 & S-115 & 117.5 & 1.77 & S-161 & 184.08 & 4.25 \\
\hline S-24 & 46.5 & 1.50 & S-70 & 91 & 0.91 & S-116 & 118 & 1.74 & S-162 & 184.58 & 3.65 \\
\hline S-25 & 47 & 1.83 & S-71 & 91.5 & 0.47 & S-117 & 118.5 & 1.69 & S-163 & 190.07 & 3.54 \\
\hline S-26 & 47.5 & 1.75 & S-72 & 92 & 1.07 & S-118 & 119 & 1.96 & S-164 & 190.57 & - \\
\hline S-27 & 48 & 1.61 & S-73 & 92.54 & -1.25 & S-119 & 119.5 & 1.75 & S-165 & 191.07 & 3.73 \\
\hline S-28 & 48.5 & 1.68 & S-74 & 93 & 1.25 & S-120 & 119.92 & 1.92 & S-166 & 191.57 & 3.34 \\
\hline S-29 & 49 & 1.57 & S-75 & 93.5 & 1.21 & S-121 & 120.5 & 1.86 & S-167 & 192.07 & 3.49 \\
\hline S-30 & 49.5 & 1.72 & S-76 & 94 & 1.06 & S-122 & 120.92 & 2.01 & S-168 & 192.57 & 3.59 \\
\hline S-31 & 50 & 1.47 & S-77 & 94.5 & 1.44 & S-123 & 135 & 2.10 & S-169 & 193.07 & 3.61 \\
\hline S-32 & 50.5 & 1.96 & S-78 & 95 & 1.24 & S-124 & 135.67 & 1.75 & $S-170$ & 193.57 & 4.17 \\
\hline S-33 & 55 & 1.79 & S-79 & 95.5 & 0.98 & S-125 & 136 & 1.87 & S-171 & 194.07 & 3.76 \\
\hline S-34 & 55.5 & 1.77 & S-80 & 96 & 0.69 & S-126 & 151.5 & 1.13 & S-172 & 194.57 & 3.96 \\
\hline S-35 & 56.08 & 1.99 & S-81 & 96.5 & 1.39 & S-127 & 152 & 1.18 & S-173 & 195 & 4.09 \\
\hline S-36 & 56.5 & 1.95 & S-82 & 97 & 1.30 & S-128 & 152.5 & 1.60 & S-174 & 195.5 & 3.77 \\
\hline S-37 & 56.92 & 1.94 & S-83 & 97.5 & 1.58 & S-129 & 152.92 & 2.43 & S-175 & 196 & 3.75 \\
\hline S-38 & 75 & 2.11 & S-84 & 98 & 1.94 & S-130 & 153.5 & 3.45 & S-176 & 196.5 & 3.89 \\
\hline S-39 & 75.5 & 1.70 & S-85 & 98.5 & 2.39 & S-131 & 154 & 4.37 & S-177 & 204.08 & 3.66 \\
\hline S-40 & 76 & 1.80 & S-86 & 99 & 1.39 & S-132 & 154.5 & 3.92 & S-178 & 204.5 & 3.01 \\
\hline S-41 & 76.46 & 1.78 & S-87 & 99.5 & 1.14 & S-133 & 155 & 4.92 & S-179 & 205 & 3.48 \\
\hline S-42 & 77 & 1.85 & S-88 & 100 & 0.64 & S-134 & 155.5 & 4.30 & S-180 & 205.5 & 3.45 \\
\hline S-43 & 77.5 & 1.51 & S-89 & 100.5 & 1.54 & S-135 & 156 & 3.83 & S-181 & 206 & 3.41 \\
\hline S-44 & 78 & 1.28 & S-90 & 101 & 2.10 & S-136 & 156.5 & 4.06 & S-182 & 206.5 & 2.61 \\
\hline S-45 & 78.5 & 1.91 & S-91 & 101.5 & 1.61 & S-137 & 157 & 4.01 & S-183 & 207 & 2.73 \\
\hline S-46 & 79 & 1.66 & S-92 & 102 & - & S-138 & 157.5 & 4.21 & S-184 & 207.5 & 2.50 \\
\hline
\end{tabular}


Table 1. continued.

\begin{tabular}{|c|c|c|c|c|c|c|c|c|c|c|c|}
\hline Sample \# & Depth $(\mathrm{ft})$ & $\delta^{13} \mathrm{C}$ VPDB & Sample \# & Depth (ft) & $\delta^{13} \mathrm{C}$ VPDB & Sample \# & Depth (ft) & $\delta^{13} \mathrm{C}$ VPDB & Sample \# & Depth (ft) & $\delta^{13} \mathrm{C}$ VPDB \\
\hline S-185 & 208 & 1.87 & S-226 & 228.5 & 0.93 & S-267 & 249 & 0.63 & S-308 & 270 & 0.50 \\
\hline S-186 & 208.5 & 1.74 & S-227 & 229 & 0.98 & S-268 & 249.5 & 0.58 & S-309 & 270.5 & 0.23 \\
\hline S-187 & 209 & 1.56 & S-228 & 229.5 & - & S-269 & 250 & 0.91 & S-310 & 275.17 & 0.59 \\
\hline S-188 & 209.5 & 1.44 & S-229 & 230 & 1.55 & S-270 & 250.5 & 0.69 & S-311 & 275.5 & 0.58 \\
\hline S-189 & 210 & 1.76 & S-230 & 230.5 & 1.18 & S-271 & 251 & 1.08 & S-312 & 276 & 0.62 \\
\hline S-190 & 210.5 & 1.38 & S-231 & 231 & 1.63 & S-272 & 251.5 & 0.64 & S-313 & 276.58 & 0.63 \\
\hline S-191 & 211 & 1.69 & S-232 & 231.5 & 1.57 & S-273 & 252 & 0.90 & S-314 & 277 & 0.53 \\
\hline S-192 & 211.5 & 1.33 & S-233 & 232 & 1.22 & S-274 & 252.5 & 0.62 & S-315 & 277.5 & 0.84 \\
\hline S-193 & 212.04 & 1.22 & S-234 & 232.5 & 1.87 & S-275 & 253 & 0.92 & S-316 & 278 & 0.65 \\
\hline S-194 & 212.58 & 1.40 & S-235 & 233 & 1.52 & S-276 & 253.5 & 1.18 & S-317 & 278.5 & 0.68 \\
\hline S-195 & 213 & 1.19 & S-236 & 233.5 & 1.67 & S-277 & 254 & 0.85 & S-318 & 279 & 0.78 \\
\hline S-196 & 213.5 & 1.28 & S-237 & 234 & 1.19 & S-278 & 255.08 & 3.40 & S-319 & 279.5 & 0.48 \\
\hline S-197 & 214 & 0.70 & S-238 & 234.5 & 0.93 & S-279 & 255.08 & 0.68 & S-320 & 280 & 0.52 \\
\hline S-198 & 214.5 & 0.91 & S-239 & 235 & 1.03 & S-280 & 256 & 0.63 & S-321 & 280.5 & 0.70 \\
\hline S-199 & 215 & 1.18 & S-240 & 235.5 & 3.72 & S-281 & 256.5 & 0.99 & S-322 & 281.08 & 0.72 \\
\hline S-200 & 215.5 & 0.53 & S-241 & 236 & 0.62 & S-282 & 257 & 0.89 & S-323 & 281.5 & 0.74 \\
\hline S-201 & 216 & 1.11 & S-242 & 236.5 & 0.43 & S-283 & 257.5 & 0.66 & S-324 & 282 & 0.61 \\
\hline S-202 & 216.5 & 0.33 & S-243 & 237 & 0.09 & S-284 & 258 & 1.02 & S-325 & 282.5 & 0.72 \\
\hline S-203 & 217 & 0.76 & S-244 & 237.5 & 0.39 & S-285 & 258.5 & 0.56 & S-326 & 283 & 0.44 \\
\hline S-204 & 217.5 & 0.76 & S-245 & 238 & 0.71 & S-286 & 259 & 0.49 & S-327 & 283.5 & 0.52 \\
\hline S-205 & 218 & 0.12 & S-246 & 238.5 & 0.99 & S-287 & 259.5 & 0.36 & S-328 & 284 & 0.53 \\
\hline S-206 & 218.5 & 0.31 & S-247 & 239 & 0.54 & S-288 & 260 & 0.88 & S-329 & 284.5 & - \\
\hline S-207 & 219 & 0.28 & S-248 & 239.5 & 1.13 & S-289 & 260.5 & 0.38 & S-330 & 284.92 & 0.43 \\
\hline S-208 & 219.5 & 0.62 & S-249 & 240 & 0.82 & S-290 & 261 & 0.31 & S-331 & 288 & 0.69 \\
\hline S-209 & 220 & 0.79 & S-250 & 240.5 & 0.67 & S-291 & 261.5 & 0.14 & S-332 & 288.5 & 1.09 \\
\hline S-210 & 220.5 & 0.60 & S-251 & 241 & 0.75 & S-292 & 262 & 0.50 & S-333 & 289 & 1.01 \\
\hline S-211 & 221 & 0.19 & S-252 & 241.5 & 0.52 & S-293 & 262.5 & 0.32 & S-334 & 289.5 & 1.03 \\
\hline S-212 & 221.5 & 1.06 & S-253 & 242 & 0.83 & S-294 & 263 & -0.07 & S-335 & 290 & 1.13 \\
\hline S-213 & 222 & 0.81 & S-254 & 242.5 & 1.22 & S-295 & 263.5 & 0.59 & S-336 & 290.5 & 1.23 \\
\hline S-214 & 222.5 & 1.12 & S-255 & 243 & 0.54 & S-296 & 264.08 & 0.17 & S-337 & 291 & 1.14 \\
\hline S-215 & 223 & 0.44 & S-256 & 243.5 & 0.68 & S-297 & 264.5 & 0.40 & S-338 & 291.5 & 1.01 \\
\hline S-216 & 223.5 & 1.42 & S-257 & 244 & 0.76 & S-298 & 265 & 0.21 & S-339 & 292 & 1.10 \\
\hline S-217 & 224 & 1.29 & S-258 & 244.5 & 0.88 & S-299 & 265.5 & 0.29 & S-340 & 292.42 & 0.99 \\
\hline S-218 & 224.5 & 1.41 & S-259 & 245 & 0.82 & S-300 & 266 & 0.25 & S-341 & 293 & 0.96 \\
\hline S-219 & 225 & 1.32 & S-260 & 245.5 & 0.68 & S-301 & 266.5 & 0.25 & S-342 & 293.5 & 0.93 \\
\hline S-220 & 225.5 & 1.33 & S-261 & 246 & 1.08 & S-302 & 267 & 0.31 & S-343 & 294 & 1.13 \\
\hline S-221 & 226 & 1.44 & S-262 & 246.5 & 0.74 & S-303 & 267.5 & -0.24 & S-344 & 294.5 & 1.10 \\
\hline S-222 & 226.5 & 1.59 & S-263 & 247 & 0.87 & S-304 & 268 & 0.45 & S-345 & 295 & 1.00 \\
\hline S-223 & 227 & 1.53 & S-264 & 247.5 & 0.55 & S-305 & 268.5 & 0.30 & S-346 & 295.5 & 0.66 \\
\hline S-224 & 227.5 & -0.25 & S-265 & 248 & 0.63 & S-306 & 268.83 & 0.14 & S-347 & 296 & 0.76 \\
\hline S-225 & 228 & 1.20 & S-266 & 248.5 & 0.68 & S-307 & 269.5 & 0.02 & & & \\
\hline
\end{tabular}

recorded a small $\delta^{13} \mathrm{C}_{\text {org }}$ excursion that spans the $L$. convolutes-S. sedgwickii zonal boundary in the Želkovice Formation of the Prague Synform. The sampling resolution from Štorch \& Frýda (2012) was fairly low in that interval, and the "excursion" is represented by only one data point just above the base of the $S$. sedgwickii Biozone. Because there was only one data point with elevated $\delta^{13} \mathrm{C}_{\mathrm{org}}$ values, it is unclear whether or not this is truly an excursion, nor is it clear if the onset of the "excursion" occurs below, at, or above the first appearance of S. sedwickii. Traditionally, 
Table 2. Garrison Core Isotope Data.

\begin{tabular}{|c|c|c|c|c|c|c|c|c|c|c|c|c|c|c|c|}
\hline $\begin{array}{l}\text { Sample } \\
\#\end{array}$ & $\begin{array}{l}\text { Depth } \\
(\mathrm{ft})\end{array}$ & $\begin{array}{c}\delta^{13} \mathrm{C} \\
\text { VPDB }\end{array}$ & $\begin{array}{c}\delta^{18} \mathrm{O} \\
\mathrm{VPDB}\end{array}$ & $\begin{array}{l}\text { Sample } \\
\#\end{array}$ & $\begin{array}{l}\text { Depth } \\
(\mathrm{ft})\end{array}$ & $\begin{array}{c}\delta^{13} \mathrm{C} \\
\text { VPDB }\end{array}$ & $\begin{array}{c}\delta^{18} \mathrm{O} \\
\mathrm{VPDB}\end{array}$ & $\begin{array}{l}\text { Sample } \\
\#\end{array}$ & $\begin{array}{l}\text { Depth } \\
\text { (ft) }\end{array}$ & $\begin{array}{c}\delta^{13} \mathrm{C} \\
\text { VPDB }\end{array}$ & $\begin{array}{c}\delta^{18} \mathrm{O} \\
\mathrm{VPDB}\end{array}$ & $\begin{array}{l}\text { Sample } \\
\#\end{array}$ & $\begin{array}{c}\text { Depth } \\
\text { (ft) }\end{array}$ & $\begin{array}{c}\delta^{13} \mathrm{C} \\
\text { VPDB }\end{array}$ & $\begin{array}{c}\delta^{18} \mathrm{O} \\
\text { VPDB }\end{array}$ \\
\hline 1 & 359.25 & -1.74 & -7.14 & 46 & 381 & 0.15 & -6.19 & 91 & 403.5 & 0.51 & -6.27 & 136 & 426 & 1.43 & -5.63 \\
\hline 2 & 359.5 & -2.11 & -7.06 & 47 & 381.5 & 0.27 & -5.95 & 92 & 404 & 0.58 & -5.90 & 137 & 426.5 & 1.30 & -5.62 \\
\hline 3 & 360 & -2.05 & -7.03 & 48 & 382 & -0.76 & -6.25 & 93 & 404.5 & 1.01 & -5.93 & 138 & 427.08 & 1.68 & -5.62 \\
\hline 4 & 360.5 & -3.25 & -7.81 & 49 & 382.5 & 0.03 & -5.99 & 94 & 405 & 0.87 & -5.90 & 139 & 427.5 & 1.43 & -5.74 \\
\hline 5 & 361 & -1.99 & -7.08 & 50 & 383 & 0.25 & -5.93 & 95 & 405.5 & 1.21 & -5.97 & 140 & 428 & 1.61 & -5.68 \\
\hline 6 & 361.5 & -1.40 & -6.69 & 51 & 383.5 & -0.58 & -5.97 & 96 & 406 & 1.34 & -5.69 & 141 & 428.67 & 1.31 & -5.68 \\
\hline 7 & 362 & -2.26 & -7.17 & 52 & 384 & -0.18 & -6.07 & 97 & 406.5 & 1.27 & -5.71 & 142 & 428.92 & -0.26 & -6.33 \\
\hline 8 & 362.5 & -1.23 & -6.82 & 53 & 384.5 & -0.36 & -6.15 & 98 & 407 & 1.05 & -5.81 & 143 & 429.5 & 2.05 & -5.59 \\
\hline 9 & 363 & -0.72 & -6.66 & 54 & 385 & -0.17 & -6.12 & 99 & 407.5 & 1.08 & -5.87 & 144 & 430 & 1.66 & -5.52 \\
\hline 10 & 363.5 & 0.89 & -5.99 & 55 & 385.5 & -0.27 & -6.22 & 100 & 408 & -0.06 & -5.77 & 145 & 430.5 & 1.20 & -5.71 \\
\hline 11 & 364 & -2.19 & -7.42 & 56 & 386 & -0.22 & -6.17 & 101 & 408.5 & 0.16 & -6.04 & 146 & 431 & 1.39 & -5.64 \\
\hline 12 & 364.5 & -2.83 & -7.49 & 57 & 386.5 & 0.12 & -6.10 & 102 & 409 & 0.37 & -6.14 & 147 & 431.5 & 1.81 & -5.63 \\
\hline 13 & 365 & -0.59 & -6.22 & 58 & 387 & 0.00 & -5.99 & 103 & 409.5 & 0.30 & -6.15 & 148 & 432 & 1.95 & -5.60 \\
\hline 14 & 365.5 & -0.73 & -6.24 & 59 & 387.5 & 0.06 & -5.90 & 104 & 410 & 0.45 & -6.05 & 149 & 432.5 & 1.82 & -5.69 \\
\hline 15 & 366 & -1.21 & -6.32 & 60 & 388 & -0.13 & -6.07 & 105 & 410.5 & 0.33 & -6.85 & 150 & 433 & 1.69 & -5.71 \\
\hline 16 & 366.5 & -1.00 & -6.23 & 61 & 388.5 & -0.48 & -6.23 & 106 & 411 & 1.18 & -5.88 & 151 & 433.5 & 2.09 & -5.59 \\
\hline 17 & 367 & -1.19 & -6.33 & 62 & 389 & -0.23 & -5.93 & 107 & 411.5 & 1.15 & -5.77 & 152 & 434 & 1.96 & -5.79 \\
\hline 18 & 367.5 & -1.12 & -6.46 & 63 & 389.5 & 0.30 & -5.87 & 108 & 412 & 0.81 & -5.78 & 153 & 434.5 & 1.78 & -5.67 \\
\hline 19 & 368 & -0.99 & -6.45 & 64 & 390 & 0.82 & -5.76 & 109 & 412.5 & 0.90 & -5.81 & 154 & 435 & -2.14 & -6.78 \\
\hline 20 & 368.5 & -1.05 & -6.45 & 65 & 390.5 & -0.20 & -5.95 & 110 & 413 & 0.87 & -5.79 & 155 & 435.58 & -0.67 & -6.53 \\
\hline 21 & 369 & -0.56 & -6.38 & 66 & 391 & -0.42 & -6.07 & 111 & 413.5 & 0.70 & -5.83 & 156 & 436 & 0.01 & -6.16 \\
\hline 22 & 369.5 & -1.00 & -6.43 & 67 & 391.5 & -0.19 & -5.81 & 112 & 414 & 0.85 & -5.85 & 157 & 436.5 & -0.39 & -6.38 \\
\hline 23 & 370 & -0.90 & -6.63 & 68 & 392 & -0.12 & -6.00 & 113 & 414.5 & 1.49 & -5.58 & 158 & 437 & -0.94 & -6.48 \\
\hline 24 & 370.5 & -0.93 & -6.45 & 69 & 392.5 & 0.39 & -5.92 & 114 & 415 & 1.82 & -5.43 & 159 & 437.5 & 0.43 & -6.17 \\
\hline 25 & 371 & -0.78 & -6.36 & 70 & 393 & -0.62 & -6.19 & 115 & 415.42 & 1.77 & -5.53 & 160 & 438 & -0.01 & -6.21 \\
\hline 26 & 371.5 & -1.09 & -6.61 & 71 & 393.5 & -0.34 & -6.23 & 116 & 416 & 1.05 & -5.62 & 161 & 438.5 & -1.68 & -6.75 \\
\hline 27 & 372 & -0.85 & -6.53 & 72 & 394 & -0.29 & -6.09 & 117 & 416.5 & 1.65 & -5.36 & 162 & 439 & 1.08 & -5.84 \\
\hline 28 & 372.5 & -1.02 & -6.48 & 73 & 394.5 & -0.32 & -6.17 & 118 & 417 & 1.72 & -5.40 & 163 & 439.5 & -0.27 & -6.14 \\
\hline 29 & 373 & -0.49 & -6.25 & 74 & 395 & 0.07 & -6.27 & 119 & 417.5 & 1.68 & -5.45 & 164 & 440 & -0.19 & -6.24 \\
\hline 30 & 373.5 & -0.45 & -6.41 & 75 & 395.5 & 0.02 & -6.06 & 120 & 418 & 0.66 & -5.59 & 165 & 440.42 & -0.19 & -6.21 \\
\hline 31 & 374 & -0.74 & -6.44 & 76 & 396 & 0.33 & -5.84 & 121 & 418.5 & 1.35 & -5.54 & 166 & 441 & 0.35 & -6.06 \\
\hline 32 & 374.42 & -0.09 & -6.12 & 77 & 396.5 & -0.17 & -6.11 & 122 & 419 & 1.03 & -5.50 & 167 & 441.5 & 0.16 & -6.25 \\
\hline 33 & 375 & -0.96 & -6.59 & 78 & 397 & 0.04 & -5.89 & 123 & 419.5 & 0.88 & -5.76 & 168 & 442 & 0.65 & -6.06 \\
\hline 34 & 375.58 & -0.77 & -6.43 & 79 & 397.5 & 0.10 & -5.97 & 124 & 420 & 0.85 & -5.58 & 169 & 442.5 & -0.20 & -6.28 \\
\hline 35 & 376 & -0.62 & -6.52 & 80 & 398 & 0.63 & -6.03 & 125 & 420.5 & 1.37 & -5.45 & 170 & 443 & 0.84 & -6.01 \\
\hline 36 & 376.5 & -0.30 & -6.25 & 81 & 398.5 & 0.57 & -5.75 & 126 & 421 & 1.58 & -5.43 & 171 & 443.5 & 0.66 & -6.02 \\
\hline 37 & 377 & -0.23 & -6.21 & 82 & 399 & 0.39 & -5.71 & 127 & 421.5 & 1.94 & -5.43 & 172 & 444 & 1.06 & -5.85 \\
\hline 38 & 377.5 & -0.33 & -6.29 & 83 & 399.5 & -0.08 & -5.92 & 128 & 422 & 2.11 & -5.40 & 173 & 444.5 & 1.10 & -5.75 \\
\hline 39 & 378 & -0.18 & -6.18 & 84 & 400.08 & 0.26 & -5.73 & 129 & 422.5 & 1.71 & -5.42 & 174 & 445 & 0.87 & -5.81 \\
\hline 40 & 378.5 & 0.19 & -5.84 & 85 & 400.5 & 0.26 & -5.87 & 130 & 423 & 1.93 & -5.34 & 175 & 445.5 & 0.19 & -5.99 \\
\hline 41 & 378.75 & 0.26 & -6.04 & 86 & 401 & 0.16 & -5.91 & 131 & 423.5 & 2.15 & -5.53 & 176 & 446 & 1.04 & -5.75 \\
\hline 42 & 379 & 0.47 & -5.96 & 87 & 401.5 & 0.41 & -6.05 & 132 & 424 & 1.24 & -5.64 & 177 & 446.5 & 1.25 & -5.73 \\
\hline 43 & 379.5 & 0.41 & -5.99 & 88 & 402 & 0.44 & -5.85 & 133 & 424.42 & 2.04 & -5.43 & 178 & 447 & 1.60 & -5.38 \\
\hline 44 & 380 & 0.15 & -5.99 & 89 & 402.5 & 0.11 & -5.75 & 134 & 425 & 1.56 & -5.61 & 179 & 447.5 & 1.64 & -5.48 \\
\hline 45 & 380.5 & -0.19 & -5.97 & 90 & 403 & 0.31 & -5.80 & 135 & 425.5 & 1.61 & -5.53 & 180 & 448 & 1.26 & -5.57 \\
\hline
\end{tabular}


Table 2. continued.

\begin{tabular}{|c|c|c|c|c|c|c|c|c|c|c|c|c|c|c|c|}
\hline $\begin{array}{l}\text { Sample } \\
\text { \# }\end{array}$ & $\begin{array}{l}\text { Depth } \\
(\mathrm{ft})\end{array}$ & $\begin{array}{c}\delta^{13} \mathrm{C} \\
\text { VPDB }\end{array}$ & $\begin{array}{c}\delta^{18} \mathrm{O} \\
\mathrm{VPDB}\end{array}$ & $\begin{array}{l}\text { Sample } \\
\#\end{array}$ & $\begin{array}{l}\text { Depth } \\
(\mathrm{ft})\end{array}$ & $\begin{array}{c}\delta^{13} \mathrm{C} \\
\text { VPDB }\end{array}$ & $\begin{array}{c}\delta^{18} \mathrm{O} \\
\mathrm{VPDB}\end{array}$ & $\begin{array}{l}\text { Sample } \\
\#\end{array}$ & $\begin{array}{c}\text { Depth } \\
(\mathrm{ft})\end{array}$ & $\begin{array}{c}\delta^{13} \mathrm{C} \\
\text { VPDB }\end{array}$ & $\begin{array}{c}\delta^{18} \mathrm{O} \\
\mathrm{VPDB}\end{array}$ & $\begin{array}{l}\text { Sample } \\
\#\end{array}$ & $\begin{array}{c}\text { Depth } \\
\text { (ft) }\end{array}$ & $\begin{array}{c}\delta^{13} \mathrm{C} \\
\text { VPDB }\end{array}$ & $\begin{array}{c}\delta^{18} \mathrm{O} \\
\text { VPDB }\end{array}$ \\
\hline 181 & 448.5 & 1.29 & -5.51 & 220 & 468 & 1.32 & -7.08 & 260 & 488.17 & -3.56 & -4.41 & 299 & 507.5 & -3.31 & -4.77 \\
\hline 182 & 449 & 1.57 & -5.58 & 221 & 468.5 & -0.96 & -5.87 & 261 & 488.5 & -2.26 & -2.00 & 300 & 508 & -2.42 & -3.06 \\
\hline 183 & 449.5 & 1.19 & -5.71 & 222 & 469 & -1.17 & -6.04 & 262 & 489 & -2.01 & -2.06 & 301 & 508.5 & -2.75 & -3.65 \\
\hline 184 & 450 & 1.56 & -5.52 & 223 & 469.5 & -1.07 & -5.79 & 263 & 489.42 & -2.13 & -2.05 & 302 & 509 & -2.53 & -1.44 \\
\hline 185 & 450.5 & 1.25 & -5.00 & 224 & 470 & 0.06 & -5.12 & 264 & 490 & -3.38 & -2.38 & 303 & 509.5 & -2.33 & -1.53 \\
\hline 186 & 451 & 0.74 & -5.32 & 225 & 470.5 & -1.29 & -5.88 & 265 & 490.5 & -3.32 & -2.11 & 304 & 510 & -2.42 & -1.70 \\
\hline 187 & 451.5 & 0.54 & -5.23 & 226 & 471 & -0.88 & -5.73 & 266 & 491 & -3.16 & -2.12 & 305 & 510.5 & -1.87 & -2.06 \\
\hline 188 & 452 & 0.10 & -5.62 & 227 & 471.5 & -1.22 & -6.03 & 267 & 491.5 & -2.47 & -2.76 & 306 & 511 & -2.97 & -3.50 \\
\hline 189 & 452.5 & -1.14 & -6.27 & 228 & 472 & -0.96 & -5.85 & 268 & 492 & -2.24 & -2.61 & 307 & 511.5 & -2.34 & -2.06 \\
\hline 190 & 453 & -0.44 & -6.06 & 229 & 472.5 & -0.57 & -6.57 & 269 & 492.5 & -2.42 & -1.93 & 308 & 512 & -2.33 & -2.08 \\
\hline 191 & 453.5 & -0.04 & -5.83 & 230 & 473 & -0.81 & -5.71 & 270 & 493 & -2.95 & -4.06 & 309 & 512.5 & -2.21 & -0.56 \\
\hline 192 & 454 & -0.60 & -6.04 & 231 & 473.5 & -0.34 & -5.37 & 271 & 493.5 & -2.56 & -2.44 & 310 & 513 & -2.05 & -2.55 \\
\hline 193 & 454.5 & -1.91 & -6.38 & 232 & 474 & -1.49 & -5.57 & 272 & 494 & -3.65 & -4.58 & 311 & 513.5 & -2.09 & -2.64 \\
\hline 194 & 455 & -0.64 & -5.98 & 233 & 474.5 & -0.59 & -5.28 & 273 & 494.5 & -3.17 & -4.12 & 312 & 514 & -2.14 & -2.20 \\
\hline 195 & 455.5 & -0.89 & -6.07 & 234 & 475 & -0.91 & -5.87 & 274 & 495 & -2.96 & -3.30 & 313 & 514.5 & -2.59 & -1.75 \\
\hline 196 & 456 & -0.27 & -6.11 & 235 & 475.5 & -0.96 & -5.67 & 275 & 495.5 & -1.69 & -0.80 & 314 & 515 & -2.91 & -1.38 \\
\hline 197 & 456.5 & -1.25 & -6.01 & 236 & 476.13 & -1.83 & -7.17 & 276 & 496 & -1.66 & -2.51 & 315 & 515.5 & -2.46 & -1.84 \\
\hline 198 & 457 & -1.07 & -6.18 & 237 & 476.5 & -1.11 & -5.60 & 277 & 496.5 & -2.99 & -3.64 & 316 & 516 & -2.45 & -2.27 \\
\hline 199 & 457.5 & -1.29 & -6.21 & 239 & 477.13 & -0.91 & -5.79 & 278 & 497 & -2.28 & -4.02 & 317 & 516.5 & -2.07 & -1.96 \\
\hline 200 & 458 & -0.89 & -6.16 & 240 & 477.45 & -1.08 & -6.00 & 279 & 497.5 & -2.92 & -3.11 & 318 & 517 & -2.11 & -2.31 \\
\hline 201 & 458.5 & -0.99 & -5.87 & 241 & 478.17 & -1.19 & -6.00 & 280 & 498 & -2.64 & -4.05 & 319 & 517.5 & -2.19 & -1.10 \\
\hline 202 & 459 & -0.72 & -5.76 & 242 & 478.67 & -1.65 & -6.65 & 281 & 498.5 & -2.85 & -4.69 & 320 & 518.17 & -2.05 & -1.89 \\
\hline 203 & 459.5 & -0.47 & -5.52 & 243 & 479.25 & -1.83 & -6.68 & 282 & 499 & -2.46 & -3.25 & 321 & 518.5 & -2.01 & -1.72 \\
\hline 204 & 460 & -0.05 & -5.29 & 244 & 479.36 & -2.87 & -6.24 & 283 & 499.5 & -2.50 & -2.95 & 322 & 519 & -1.39 & -2.00 \\
\hline 205 & 460.5 & -0.36 & -5.51 & 245 & 479.92 & -4.20 & -5.61 & 284 & 500 & -2.96 & -2.95 & 323 & 519.33 & -1.12 & -1.76 \\
\hline 206 & 461 & -0.75 & -5.53 & 246 & 480.5 & -2.62 & -5.05 & 285 & 500.5 & -2.61 & -2.10 & 324 & 520 & -0.65 & -2.01 \\
\hline 207 & 461.5 & -0.36 & -4.95 & 247 & 481.25 & -3.59 & -5.40 & 286 & 501 & -2.07 & -2.41 & 325 & 520.5 & -0.26 & -2.19 \\
\hline 208 & 462 & -1.17 & -6.15 & 248 & 481.5 & -3.02 & -5.76 & 287 & 501.5 & -2.38 & -2.37 & 326 & 521 & -0.33 & -2.79 \\
\hline 209 & 462.5 & -0.73 & -6.21 & 249 & 482 & -2.56 & -5.61 & 288 & 502 & -2.02 & -2.20 & 327 & 521.5 & -0.71 & -2.41 \\
\hline 210 & 463 & -0.92 & -6.34 & 250 & 482.5 & -2.40 & -2.52 & 289 & 502.5 & -2.53 & -3.32 & 328 & 522 & -0.10 & -2.52 \\
\hline 211 & 463.5 & -0.78 & -6.01 & 251 & 483 & -2.78 & -3.46 & 290 & 503 & -2.70 & -2.81 & 329 & 522.5 & -0.31 & -2.44 \\
\hline 212 & 464 & -0.89 & -6.08 & 252 & 483.5 & -2.72 & -3.56 & 291 & 503.5 & -2.82 & -4.24 & 330 & 523 & -0.53 & -2.41 \\
\hline 213 & 464.5 & -1.86 & -6.52 & 253 & 483.75 & -2.89 & -6.29 & 292 & 504 & -2.61 & -3.20 & 331 & 523.5 & -0.67 & -2.48 \\
\hline 214 & 465 & -1.87 & -6.71 & 254 & 484.64 & -2.32 & -5.29 & 293 & 504.5 & -2.60 & -3.48 & 332 & 524 & -0.40 & -2.35 \\
\hline 215 & 465.5 & -0.16 & -5.09 & 255 & 485.71 & -2.40 & -3.90 & 294 & 505 & -1.93 & -2.49 & 333 & 524.5 & -0.28 & -2.41 \\
\hline 216 & 466 & -1.75 & -7.15 & 256 & 486.13 & -2.25 & -5.29 & 295 & 505.5 & -2.45 & -3.64 & 335 & 525.5 & -0.66 & -2.48 \\
\hline 217 & 466.5 & -1.07 & -5.58 & 257 & 486.58 & -2.97 & -4.21 & 296 & 506 & -2.14 & -3.05 & 336 & 526 & -0.48 & -2.46 \\
\hline 218 & 467 & -2.92 & -4.63 & 258 & 487 & -3.53 & -5.10 & 297 & 506.5 & -2.68 & -3.02 & 337 & 526.5 & -0.55 & -2.47 \\
\hline 219 & 467.5 & -3.22 & -6.58 & 259 & 487.5 & -2.47 & -2.57 & 298 & 507 & -2.49 & -2.60 & & & & \\
\hline
\end{tabular}

several samples illustrating a rising limb and a falling limb is desired before an 'excursion' is recognized. Melchin et al. (2015) recorded numerous upper Aeronian $\delta^{13} \mathrm{C}_{\mathrm{org}}$ excursions in the Ross Brook Formation of Nova Scotia. The onset of the lowermost excursion occurs between $5 \mathrm{~m}$ and $5.5 \mathrm{~m}$ above the first appearance of $S$. sedgwickii, which they tentatively correlated with the "convolutes-sedgwickii boundary" excursion in the Želkovice Formation. Current data from the Welsh Basin indicates that the first occurrences of Stricklandia laevis and S. sedgwickii are coincident (Davies et al. 2013, 2016), meaning the onset of the lowermost excursions reported in from Štorch \& Frýda 


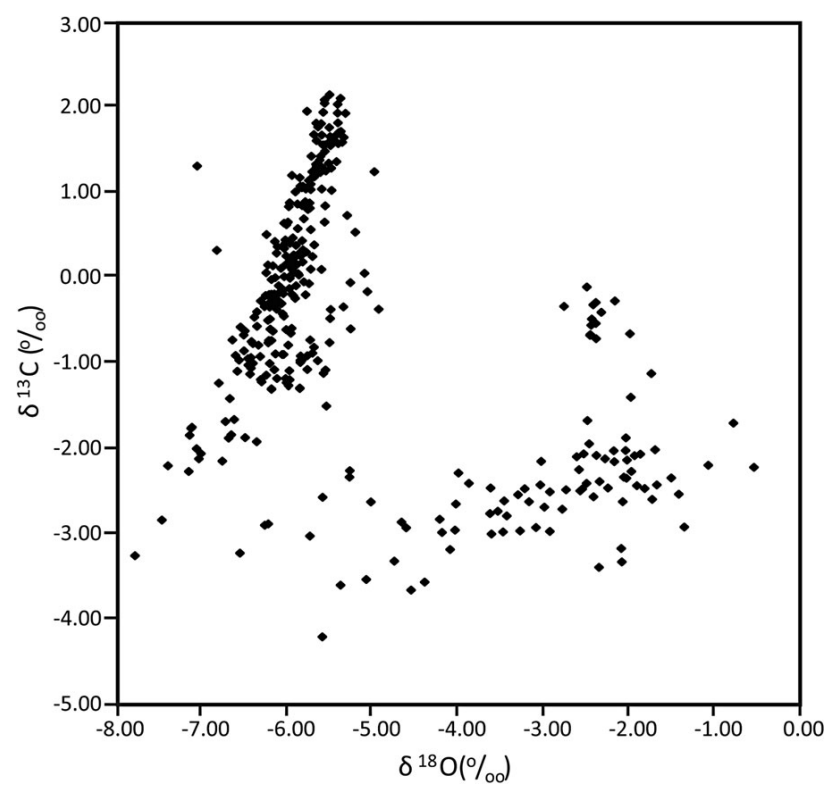

Figure 7. Cross plot of carbon and oxygen isotopic values from the Garrison Core. Note the strong linear correlation of samples with lower $\delta^{18} \mathrm{O}$ values.

(2012) and Melchin et al. (2015) likely occur above the first occurrence of $S$. laevis. Since $S$. laevis first appears in the Farmers Creek Member, the excursion in the underlying lower Hopkinton member is likely stratigraphically lower than any of the excursions of Štorch \& Frýda (2012) and Melchin et al. (2015).

McAdams et al. (2017) did not record any similar excursions to the one observed in the lower Hopkinton from the SS-10 Core, which may be due to the greater thickness of the Hopkinton Formation in Jones County (approximately 140 feet) than in Johnson County (approximately 45 feet). Because the excursion recorded in this study from the lower Hopkinton Formation is of small thickness and low-magnitude, it could have been smoothed out by time averaging due to slow deposition, or the interval could be missing entirely from the section in Johnson County studied by McAdams et al. (2017).

Most of the isotope values in the upper part of the Picture Rock Member and BCQ Member within the SS-10 Core are slightly elevated compared with baseline values from the lower Hopkinton member. The values decrease from a high of nearly $+4 \%$ in the Picture Rock Member to values scattered around $+1 \%$ at 90 feet $(27.4 \mathrm{~m})$, and then slightly rise again. We tentatively interpret this feature as the trough between the two peaks of the Valgu Excursion present in the Garrison and Knapp Creek cores (Fig. 9).

The $\delta^{13} \mathrm{C}$ data from the Garrison Core are somewhat noisy (Fig. 4), making identification of baseline values, and therefore deviation from these, difficult. The variability in the data is likely due to fluid/rock interactions during diagenesis and karstification processes. The isotope values of carbon and oxygen show two distinct relationships (Fig. 7). The cluster with the lighter $\delta^{18} \mathrm{O}$ values shows a linear to slightly concave-up trend, and the cluster with heavier $\delta^{18} \mathrm{O}$ values shows a linear to slightly concave-up trend, but with more scatter of the data. Banner \& Hanson (1990) found that linear relationships between carbon and oxygen isotopes in carbonates represent interactions between marine and diagenetic calcite, and that curved, concave-up trends indicate freshwater-saltwater mixing during diagenesis. Both of these processes are likely to have occurred after the deposition of the units studied in the Garrison Core. The brecciated chert beds of the Hopkinton (Fig. 5B) likely indicate karst collapse events, and a definite karst surface is visible in the uppermost BCQ Member (Fig. 5A). There are numerous vugs and veins filled with large calcite crystals throughout the Blanding and Hopkinton formations (Fig. 5D), indicating extensive post-depositional fluid movement and calcite recrystallization. The linear to slightly curved trends of the carbon and oxygen isotope data, karst surfaces, and calcite vug- and vein-fill may provide further evidence in support of the explanation of Witzke (1981) and Ludvigson et al. (1992) that the influx of meteoric phreatic fluids prevented dolomitization of the LPC and other limestones of Iowa.

Despite the diagenetic alteration of the rocks and subsequent alteration of $\delta^{13} \mathrm{C}$ values, one distinct isotope excursion in the uppermost Picture Rock Member (Hopkinton Formation) through most of the BCQ Member can be distinguished from baseline values in the Garrison Core. This excursion can confidently be identified as the Valgu Excursion, because conodonts diagnostic of the Pterospathodus eopennatus Superzone were recovered at 449 feet (136.9 m) in the core (Waid \& Cramer 2017). The end of the excursion is placed at 380 feet $(115.8 \mathrm{~m})$ in the core, where isotope values sharply decrease to baseline values of 0 to $-1 \%$. The Valgu Excursion was also recorded in the uppermost Picture Rock and lower BCQ members in Johnson County by McAdams et al. (2017), where it has a similar, doublepeaked shape to that from the Garrison Core. The excursion interval is expanded in the Garrison Core relative to the Knapp Creek Core (Johnson County, McAdams et al. 2017). The excursion spans roughly 70 feet $(\sim 21 \mathrm{~m})$ of strata assignable to the in Benton County, compared to the 25 feet ( 7.6m) of in Johnson County (Fig. 9).

There is a pronounced change in isotope values at 521 feet in the Garrison Core, from values scattered around $-0.5 \%$ below, to values scattered around $-2 \%$ above (Fig. 4). This abrupt change in values is due to the Blanding Formation unconformably overlying the Maquoketa Formation. The Iowa Geological Survey has traditionally identified the green, argillaceous floatstone from 521-526 feet in the Garrison Core (as well as numerous other cores throughout the state) as part of the Silurian Blanding Formation (e.g., Witzke 1981). However, all 


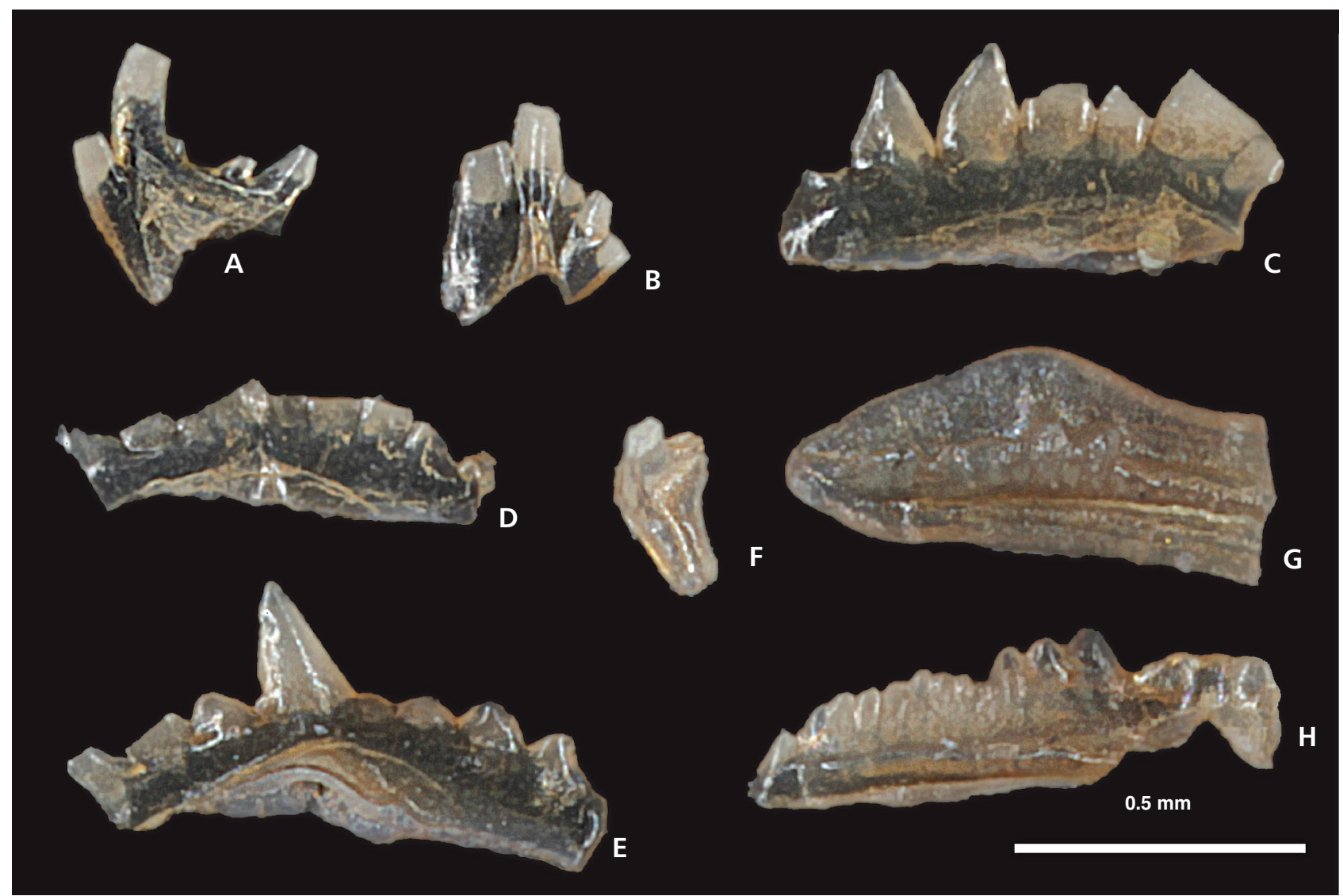

Figure 8. Conodonts from the uppermost Maquoketa Formation in the Garrison Core. • A-E - Plectodina furcata inclinata (Glennister, 1957); A - Sc element, posterior-lateral view, GR 521.17-522.0 ft, SUI 142356; B - Sb? element, posterior view, GR 521.17-522.0 ft, SUI 142357; C - Pa element, lateral view, GR 521.17-522.0 ft, SUI 142358; D - Pa element, lateral view, GR 521.17-522.0 ft, SUI 142359; E - Pa element, lateral view, GR 525.58-526.50 ft, SUI 142360. • F-H Amorphognathus sp.; F - Pc? element fragment, oral view, GR 525.58-526.50 ft, SUI 142361; G - Pa element fragment, oral view, GR 525.58-526.50ft, SUI 142362; H - Pa element fragment, lateral view, GR 525.58-526.50 ft, SUI 142363.

complex conodonts collected from samples of that unit in this study are of genera restricted to the Ordovician System (Plectodina, Amorphognathus; Fig. 8). There are abundant angular dolomudstone rip-up clasts in this interval (Fig. 5C), and the conodonts were predominantly poorly preserved and very fragmented, which allows for the possibility that the Ordovician conodonts are from Ordovician material that was re-deposited during the Silurian. However, the complete absence of Silurian conodonts indicates that it is more likely that both the intraclasts and the matrix surrounding the clasts were deposited during the Ordovician. This interpretation is reinforced by the abrupt change in isotope values above the floatstone unit, which suggests a significant unconformity.

The integration of high-resolution $\delta^{13} \mathrm{C}_{\text {carb }}$ chemostratigraphy, conodont biostratigraphy, and brachiopod biostratigraphy in the Silurian of Iowa has allowed for the first regional chronostratigraphic correlations at a resolution finer than stage level (Fig. 9). Based on conodont data, the base of the Pt. celloni Superzone can be correlated between the Knapp Creek and Garrison cores, and the base of the Superzone occurs within the BCQ Member in both locations. The onset of the Valgu Excursion is absent in the SS-10 Core due to missing core, but its location can be confined to the middle to upper part of the Picture Rock Member - above the descending limb of the sedgwickii graptolite zone excursion, and below what is interpreted to be the descending limb and middle trough of the Valgu Excursion. The onset of the sedgwickii graptolite zone excursion occurs in the lower part of the Farmers Creek Member in both the Knapp Creek and SS-10 cores. No distinctive excursion is recorded in the Farmers Creek Member from the Garrison Core, which may be due to diagenetic alteration or removal of strata during karstification. The small excursion in the lower Hopkinton member is present only in the SS-10 Core.

\section{Conclusion}

The late Aeronian sedgwickii graptolite zone carbon isotope excursion and a heretofore unrecorded Aeronian 


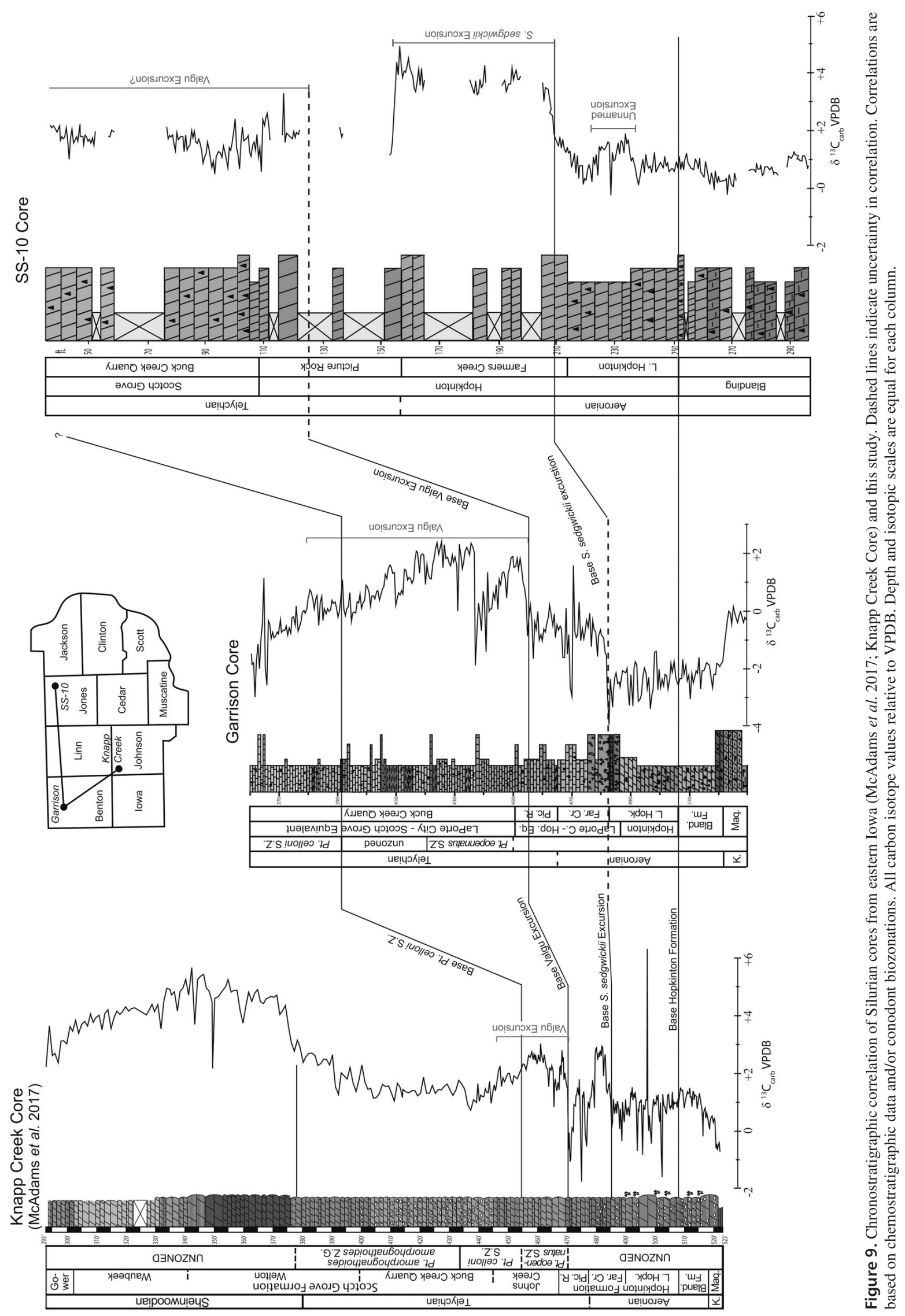


excursion occur in the Hopkinton Formation in the SS-10 Core (Jones County). The Valgu Excursion was recorded from the uppermost Hopkinton Formation and the Buck Creek Quarry Member of the Scotch Grove Formation in the Garrison Core. The Valgu and sedgwickii graptolite zone excursions can be correlated to Johnson County, where they were recorded by McAdams et al. (2017). The oxygen and carbon isotope values from the Garrison Core and the evidence for post-diagenetic karstification and fluid movement through the units provides evidence that the dolomitization process was halted by the influx of meteoric phreatic water. This study shows the first high-resolution chronostratigraphic correlation of Silurian units in Iowa, and highlights the utility of carbon isotope chemostratigraphy as a tool for chronostratigraphic correlation in strata with poor biostratigraphic control. The results demonstrate that much of the Aeronian and Telychian stages are preserved in carbonate strata in Iowa and that the East-Central Iowa Basin can provide important records for global paleoclimatic reconstruction.

\section{Acknowledgments}

We thank Neo E.B. McAdams and Alyssa M. Bancroft for their assistance in the field, and the University of Iowa Paleontology Repository for providing the photography equipment used in the study. We are grateful for the thorough reviews of P. Männik and D.K. Loydell. B.J. Witzke and E. Finzel provided helpful feedback on an earlier version of the manuscript. We also thank the Iowa Geological Survey for providing the cores used in this study. This work was partially supported by NSF grant \# CAREER-1455030 to B.D. Cramer and a GSA Foundation Graduate Research Grant to C.B. Waid. This is a contribution to the International Geoscience Programme (IGCP) Project 591 - The Early to Middle Paleozoic Revolution.

\section{References}

Banner, J. \& Hanson, G. 1990. Calculation of simultaneous isotopic and trace element variations during water-rock interaction with applications to carbonate diagenesis. Geochimica et Cosmochimica Acta 54, 3123-3137. DOI 10.1016/0016-7037(90)90128-8

Bergström, S., KlefFner, M. \& Schmitz, B. 2012. Late Ordovician-Early Silurian $\delta^{13} \mathrm{C}$ chemostratigraphy in the Upper Mississippi Valley: implications for chronostratigraphy and depositional interpretations. Earth and Environmental Science Transactions of the Royal Society of Edinburgh 102, 159-178. DOI 10.1017/S1755691012011061

Boucot, A. \& EhLERs, G. 1963. Two new genera of Stricklandid brachiopods. Contributions from the Museum of Paleontology, The University of Michigan 18, 47-66.

Branson, E. \& Mehl, M. 1933. Conodont Studies. Missouri University Studies 8, 349 pp.

Cramer, B.D., Brett, C.E., Melchin, M.J., Männik, P., KlefFner,
M.A., Mclaughlin, P.I., Loydell, D.K., Munnecke, A., Jeprsson, L., Corradini, C., Brunton, F.R. \& Saltzman, M.R. 2011. Revised correlation of Silurian Provincial Series of North America with global and regional chronostratigraphic units and $\delta^{13} \mathrm{C}_{\text {carb }}$ chemostratigraphy. Lethaia $44,185-202$.

DOI 10.1111/j.1502-3931.2010.00234.x

Davies, J., Waters, R., Molyneux, S., Williams, M., Zalasiewicz, J., Vandenbroucke, T. \& Verniers, J. 2013. A revised sedimentary and biostratigraphical architecture for the Type Llandovery area, Central Wales. Geological Magazine 150, 300-332. DOI 10.1017/S0016756812000337

Davies, J., Waters, R., Molyneux, S., Williams, M., Zalasiewicz, J. \& VAndenbroucke, T. 2016. Gauging the impact of glacioeustasy on a mid-latitude early Silurian margin, mid Wales, UK. Earth-Science Reviews 156, 82-107. DOI 10.1016/j.earscirev.2016.02.004

Ethington, R. 1959. Conodonts of the Ordovician Galena Formation. Journal of Paleontology 33, 257-292.

GlenNister, A. 1957. The conodonts of the Ordovician Maquoketa Formation in Iowa. Journal of Paleontology 33, 715-736.

Jeppsson, L. 1997. A new latest Telychian, Sheinwoodian and early Early Homerian (Early Silurian) Standard Conodont Zonation. Transactions of the Royal Society of Edinburgh: Earth Sciences 88, 91-114. DOI $10.1017 /$ S0263593300006854

JepPSSON, L. \& Anehus, R. 1995. A buffered formic acid technique for conodont extraction. Journal of Paleontology 69, 790-794. DOI 10.1017/S0022336000035319

Johnson, M. 1977. Succession and replacement in the development of Silurian brachiopod populations. Lethaia 10, 83-93. DOI 10.1111/j.1502-3931.1977.tb00595.x

Johnson, M. 1983. New member names for the lower Silurian Hopkinton Dolomite of eastern Iowa. Proceedings of the Iowa Academy of Science 90, 13-18.

Johnson, M. 1987. Extent and bathymetry of North American platform seas in the early Silurian. Paleoceanography 2, 185-211. DOI 10.1029/PA002i002p00185

JonES, O.T. 1925. The Geology of the Llandovery district: part I. The Southern Area. Quarterly Journal of the Geological Society, 81, 344-388. DOI 10.1144/GSL.JGS.1925.081.01-04.15

Kaljo, D. \& Martma, T. 2006. Application of carbon isotope stratigraphy to dating the Baltic Silurian rocks. GFF 128, 123-129. DOI 10.1080/11035890601282123

Kaljo, D., KiIPli, T. \& Martma, T. 1997. Carbon isotope event markers through the Wenlock-Pridoli sequence at Ohesaare (Estonia) and Priekule (Latvia). Palaeogeography, Palaeoclimatology, Palaeoecology 132, 211-223. DOI 10.1016/S0031-0182(97)00065-5

Kaljo, D., KiIPli, T. \& Martma, T. 1998. Correlation of carbon isotope events and environmental cyclicity in the East Baltic Silurian, 297-312. In Landing, E. \& Johnson, M. (eds) Silurian Cycles: Linking Dynamic Stratigraphy with Atmospheric, Oceanic, and Tectonic Changes. New York State Museum Bulletin 491.

Kaljo, D., Martma, T., Grytsenko, V., Brazauskas, A. \& KAMINSKAS, D. 2012. Př́ídolí carbon isotope trend and upper Silurian to lowermost Devonian chemostratigraphy based on sections in Podolia (Ukraine) and the East Baltic area. Esto- 
nian Journal of Earth Sciences 61, 162-180.

DOI 10.3176/earth.2012.3.03

Kaljo, D., Martma, T., MänNiK, P. \& ViIRA, V. 2003. Implications of Gondwana glaciations in the Baltic Late Ordovician and Silurian and a carbon isotopic test of environmental cyclicity. Bulletin de la Societe Geologique de France 174, 59-66. DOI 10.2113/174.1.59

Ludvigson, G.A., WitzKe, B.J. \& GonZÁLEZ, L. 1992. Observations on the diagenesis and stable isotopic compositions of Silurian carbonates in Iowa. Field trip guidebook to Silurian exposures in Jones and Linn Counties. Iowa Geological Survey Guidebook Series 11, 73-83.

Macke, D. 1995. Illinois Basin Province (064). In Gautier, D., Dolton, G., TAKAhashi, K. \& VARnes, K. (eds) National assessment of United States oil and gas resources - Results, methodology, and supporting data: United States Geological Survey Digital Data Series DDS-30, Release 2, accessed 4/20/15 at http://certmapper.cr.usgs.gov

MänNiK, P. 1998. Evolution and taxonomy of the Silurian conodont Pterospathodus. Paleontology 41, 1001-1050.

MäNNIK, P. 2007a. An updated Telychian (Late Llandovery, Silurian) conodont zonation based on Baltic faunas. Lethaia 40, 45-60. DOI 10.1111/j.1502-3931.2006.00005.x

MÄNNIK, P. 2007b. Recent developments in the Upper Ordovician and lower Silurian conodont biostratigraphy in Estonia. Estonian Journal of Earth Sciences 56, 35-46.

McAdams, N.E.B., Bancroft, A.M., Cramer, B.D. \& Witzke, B.J. 2017. Integrated carbon isotope and conodont biochemostratigraphy of the Silurian (Aeronian-Telychian) of the East-Central Iowa Basin, Iowa, USA. Newsletters on Stratigraphy 50, 391-416. DOI 10.1127/nos/2017/0375

Melchin, M.J. \& Holmden, C. 2006. Carbon isotope chemostratigraphy of the Llandovery in Arctic Canada: implications for global correlation and sea-level change. GFF 128, 173-180. DOI 10.1080/11035890601282173

Melchin, M.J., MacRae, K.D. \& Bullock, P. 2015.A multi-peak organic carbon isotope excursion in the late Aeronian (Llandovery, Silurian): evidence from Arisaig, Nova Scotia, Canada. Palaeoworld 24, 191-197.

DOI 10.1016/j.palwor.2014.12.004

Melchin, M.J., SAdler, P.M. \& Cramer, B.D. 2012. Chapter 21: The Silurian Period, 525-588. In Gradstein, F., OGG, J., Schmitz, M. \& OGG, G.(eds) The Geologic Time Scale 2012. Elsevier, New York.
Metzger, R. 2005. Conodont biostratigraphy of the Scotch Grove and LaPorte City formations (late Llandovery-early Wenlock; Silurian) in eastern Iowa. Bulletins of American Paleontology 369, 93-104.

Munnecke, A., Calner, M., Harper, D.A.T. \& Servais, T. 2010. Ordovician and Silurian sea-water chemistry, sea level, and climate: A synopsis. Palaeogeography, Palaeoclimatology, Palaeoecology 296, 389-413.

DOI 10.1016/j.palaeo.2010.08.001

SAltZMAn, M.R. 2002. Carbon isotope $\left(\delta^{13} \mathrm{C}\right)$ stratigraphy across the Silurian-Devonian transition in North America: evidence for a perturbation of the global carbon cycle. Palaeogeography, Palaeoclimatology, Palaeoecology 187, 83-100. DOI 10.1016/S0031-0182(02)00510-2

Saltzman, M.R. \& Thomas, E. 2012. Chapter 11: Carbon Isotope Stratigraphy, 201-232. In GradsteIn, F., OGG, J., Schmitz, M. \& OGG, G.(eds) The Geologic Time Scale 2012. Elsevier, New York.

ŠTorCh, P. \& FrÝdA, J. 2012. The late Aeronian graptolite sedgwickii Event, associated positive carbon isotope excursion and facies changes in the Prague Synform (Barrandian area, Bohemia). Geological Magazine 149, 1089-1106. DOI 10.1017/S001675681200026X

Torsvik, T., Smethurst, M., Meert, J., Van der Voo, R., McKerrow, W., Brasier, M., Sturt, B. \& Walderhaug, H. 1996. Continental break-up and collision in the Neoproterozoic and Palaeozoic - A tale of Baltica and Laurentia. Earth-Science Reviews 40, 229-258. DOI 10.1016/0012-8252(96)00008-6

WAID, C.B. \& CRAmER, B.D. 2017. Telychian (Llandovery, Silurian) conodonts from the LaPorte City Formation of eastern Iowa (East-Central Iowa Basin) and their implications for global Telychian conodont biostratigraphic correlation. Palaeontologia Electronica 20, 1-37.

Walliser, O. 1964. Conodonten des Silurs. Abhandlungen des Hessischen Landesamtes für Bodenforschung 41,1-106.

WitzKe, B. 1981. Stratigraphy, depositional environments, and diagenesis of the eastern Iowa Silurian sequence. 574 pp. Ph.D. thesis, The University of Iowa, Iowa City, USA.

WitZKe, B. 1992. Silurian stratigraphy and carbonate mound facies of Eastern Iowa. Field trip guidebook to Silurian exposures in Jones and Linn Counties, Iowa Geological Survey Guidebook Series 11, 3-63. 